This is the peer reviewed version of the following article: Nolasco-Soria, Héctor, Héctor-Rodrigo Nolasco-Alzaga, and Enric Gisbert. 2020. "The Importance Of PepsinLike Acid Protease Quantification In Aquaculture Studies: A Revision Of Available Procedures And Presentation Of A New Protocol For Its Assessment". Reviews In Aquaculture. Wiley. doi:10.1111/raq.12417., which has been published in final form at https://doi.org/10.1111/raq.12417. This article may be used for non-commercial purposes in accordance with Wiley Terms and Conditions for Use of Self-Archived Versions http://www.wileyauthors.com/self-archiving.

Document downloaded from: 


\title{
The importance of pepsin-like acid protease quantification in aquaculture studies: a revision of available procedures and presentation of a new protocol for its assessment
}

Hector Nolasco-Soria1, Hector-Rodrigo Nolasco-Alzaga1 and Enric Gisbert2

1 Centro de Investigaciones Biológicas del Noroeste, La Paz, México

2 Institut de Recerca i Tecnologia Agroalimentaries, Centre de Sant Carles de la Rápita (IRTA-SCR), Sant Carles de la Rápita, Spain

\begin{abstract}
Assessing the activity of acid pepsin-like protease is a common procedure in many biological, physiological and nutritional studies in gastric fish species. After reviewing the available literature on fish digestive acid proteases (stomach acid pepsin-like proteases), especially those species of relevance for aquaculture purposes, published during a time span of ten years (2008 - 2018), authors detected some possible methodological and/or interpretative inconsistencies in this kind of studies when quantifying pepsin-like enzymes. Thus, we concluded that special attention should be paid on the following issues when assessing digestive acid protease activity: $i$ ) the proper preparation of stomach extracts, $i$ ) the use of the proper reaction conditions at the normal range of physiological $\mathrm{pH}$ and temperature values, and iii) the proper quantification of the number of peptide bonds hydrolyzed for acid protease unit calculation. The implementation of these recommendations, and the proposal of more suitable (previously tested) methodological steps, will promote the standardization of acid pepsin-like protease analytical procedures,
\end{abstract}


as well as improve the reliability of comparative studies dealing with this proteolytic enzyme between different fish species of aquacultural importance.

Keywords: protocol, fish, stomach, acid pepsin-like protease, enzyme unit.

\section{Introduction}

\subsection{The relevance of assessing the activity of digestive enzymes in cultured fish: the} case of pepsin-like acid protease

Digestive enzyme activities in fishes are indicative of their feeding ecology and trophic niche in natural conditions; thus, correlating well with their diet (German et al. 2004). In this context, it is well accepted that the structure and function of the digestive system of fishes strongly are correlated with their feeding habits, and for this reason, the characterization of digestive enzyme activities is of special relevance in aquaculture studies where there is a need of synchronizing the function of the digestive system with the rearing procedures and nutritional strategies. Thus, assessing the activity of digestive enzymes is a common procedure in many biological, physiological and nutritional studies. Among the repertoire of digestive enzymes, pepsin-like acid proteases are the main enzymes involved in protein digestion due to their activity under the acid environment of the stomach. Evaluating the activity of acid pepsin-like proteases in nutritional studies is widely used when researchers aim to evaluate the digestive competence of gastric fish species throughout their ontogeny. In addition, the measurement of this endoprotease is considered as a valuable biomarker for proper adapting feeding and rearing protocols to fish digestive capacities along ontogeny (Zambonino-Infante \& Cahu 2001; Lazo et al. 
2011). In this context, the transition from a larval-like protein digestion mode, based on the participation of alkaline proteases (trypsin, chymotrypsin, and carboxypeptidases among others), to a juvenile/adult one characterized by an acid environment and pepsin-like enzymes is generally considered as an optimal point for larval weaning onto microdiets in fish hatcheries (Rønnestad et al. 2013). These enzymes analyses are also commonly used for assessing the impact of a certain type of diet or nutrient on the functionality and/or maturation of digestive organs (Zambonino-Infante \& Cahu, 2007). In particular, under normal rearing conditions the maturation of the digestive function (luminal digestion) is characterized by a decrease in the activity of alkaline proteases concomitantly to an increase of pepsin-like enzyme levels. Thus, a delay in the onset of acidic digestion may be considered indicative of a suboptimal diet or rearing procedure as the decoupling of the alkaline and acid digestion indicates (Zambonino-Infante \& Cahu, 2001). Furthermore, assessing the levels of pepsin-like proteases and their secretion rates, as well of those from other digestive enzymes, may be also used for optimizing dietary protein levels in aquafeed, as well as understanding the regulatory role of nutrients in digestive physiology.

In addition, the assessment of digestive enzymes, mainly gastric enzymes like pepsin, may be used in in vitro digestibility studies to evaluate the capacity of gastric fish species to hydrolyse different feed ingredients (i.e. fish meal of different origin and quality, and alternative protein sources), information that is of great value for assessing the digestibility of ingredients, as well as improving and refining aquafeed formulations (Dimes \& Haard, 1994; Moyano et al. 2014). In vitro digestibility analyses, using a known number of acid pepsin-like protease units for acidic digestion, and alkaline protease units for alkaline digestion, provide a fast, reliable and low cost effective alternative to in vivo trials when a large number of fish and methodological replicates are needed (Moyano et al. 2014). 
Due to its multiple applications in nutritional and physiological studies related to aquaculture fish species, the analysis of pepsin-like activity in gastric species is of relevance; however, reliable, reproducible and standardised procedures are needed for these kind of studies.

\subsection{Pepsin activity determination}

Assessing the activity of acid pepsin-like protease is generally conducted by means of spectrophotometric procedures after the recovery of the digestion products (Anson 1938). The spectrophotometric methods for protease quantification are based on the incubation of a working solution (buffer) mixed with a specific substrate like hemoglobin for acid pepsin-like protease (Anson 1938); azocasein, casein or hemoglobin for alkaline proteases (Sarath et al. 1989) and with an extract containing the targeted enzyme or mixture of enzymes of interest from the animal digestive tract. The incubation of the substrate dissolved in the working solution and the enzyme results in the hydrolysis of the substrate, which allows the quantification of its activity. In the case of hemoglobin hydrolysis, products are measured by changes in the absorbance of trichloroacetic acid (TCA) nonprecipitable hydrolyzed products due to colour development by the Folin-Ciocalteau reagent (Anson 1938), or direct absorbance reading at $\lambda=280 \mathrm{~nm}$ (Worthington 1993). In the case of alkaline hydrolysis, when using casein or hemoglobin substrates, absorbance is also measured at $\lambda=280 \mathrm{~nm}$ or at $\lambda=440 \mathrm{~nm}$ when using azocasein (Sarath et al. 1989), or at $\lambda=520 \mathrm{~nm}$ when using azo dye-impregnated collagen (azocoll) (Walter 1984) as substrates.

Regardless of the particular and extensive use of these analytical procedures, the authors of this contribution, while checking the available literature, have detected some common inconsistencies in the preparation of enzymatic crude extracts, and in the determination of the acid pepsin-like protease activity. The above-mentioned 
inconsistencies may affect the proper quantification of protease activity and the interpretation of the results derived from those analyses. Thus, the present contribution is focused on two issues: a). providing an integrative and extensive review of different studies dealing with acid protease determination in fish with special attention to those interest for the aquaculture industry (Section 2) as well as b). proper recommendations regarding the standardization of the analytical procedures for acid protease quantification (Section 3).

\section{Reviewing the literature dealing with pepsin-like acid protease quantification in}

\section{fishes}

\subsection{Methodological approach}

Authors decided to evaluate different procedures and methodologies used by pepsin-like acid protease quantification by means of a bibliographic search using the Web of Science Core Collection $^{\mathrm{TM}}$ (www.webofknowledge.com; Thomson Reuters ${ }^{\mathrm{TM}}$ ) in order to decipher whether this analytical procedure may be improved. The following search chain "acid protease $A N D$ fish" was selected to evaluate the methodology used for acid pepsin-like acid protease quantification in the literature, resulting in a total of 54 published articles from 2008 to 2018. After removing the studies dealing with the microbial proteases or fish hydrolysates, authors used a final database of 31 articles for their review, $94 \%$ of them related to aquaculture fish species (Supplementary file 1). These articles were revised to identify which methodology was used for acid pepsin-like acid protease quantification, as well as the biological material used for those analyses.

\subsection{Bibliographic analysis, results and discussion}

2.2.1 Sample preparation to determine pepsin-like acid protease activity 
As expected, the analysis of the literature indicated that the tissues studied belonged to either larvae or digestive tracts isolated from juvenile or adult fish. Regarding the studies in fish larvae, $50 \%$ of them used the complete organism and the rest of them removed the head and tail to work with just the abdominal region for the preparation of the extracts. In the studies using the digestive tract, $73.7 \%$ of them prepared their digestive enzyme extracts using only the stomach and $26.3 \%$ used the entire digestive system (viscera). The amounts of tissue reported in these studies ranged from 15 to $35 \mathrm{mg} / \mathrm{mL}$ ( 66 to 28 volumes of extraction solution per weight of tissue) for larvae, and $50-250 \mathrm{mg} / \mathrm{mL}$ for stomach when dealing with juveniles or adult fish. In general, volumes of extraction solution by weight of tissue were from 2 to 20 for entire stomachs.

Regarding the extraction solution for analytical purposes, $22.6 \%$ of authors used distilled water, $9.7 \%$ of them used an acid buffer $(\mathrm{pH} 2-3), 41.9 \%$ used a neutral-alkaline buffer ( $\mathrm{pH} 7-8)$, and the rest did not indicate which extraction solution or buffer they used for stomach homogenization. Following up tissue homogenization, enzymatic extracts need to be clarified in order to remove all tissue debris, a step that also varies considerably depending on the consulted source (Table 1). Thus, the clarification of the enzymatic extracts is performed by centrifugation with RCF values that range from 1,100 to $28,230 \mathrm{x}$ $g$, and centrifugation times that also greatly vary from 3 to $30 \mathrm{~min}$ (at $4-5{ }^{\circ} \mathrm{C}$ ). In addition, only $54.8 \%$ of the studies applied RCF values greater than $10,000 \times$ x $g$ (Table 1).

Regarding the amount of tissue utilized to prepare the enzyme extract, considering that a minimum volume of $100 \mu \mathrm{l}$ of extract can be used to quantify the acid protease activity, a $1 \mathrm{~mL}$ sample of crude extract would be sufficient. When a weight:volume ratio of 1:5 is implemented, it is proposed to use $200 \mathrm{mg}$ of larvae per $\mathrm{mL}$ of enzyme extract, if possible. However, special attention should be paid when considering the amount of tissue for sample preparation. It is generally recommended to remove the head and tail from 
larvae in order to reduce proteins of different origin (i.e., muscular tissue) than those from the digestive system. This is particularly important in enzyme purification processes. Regardless of this recommendation, the head and tail separation from the abdominal cavity is difficult to be standardized and should be also conducted in a cold plate $\left(0-4^{\circ} \mathrm{C}\right)$ in order to prevent sample deterioration and the loss of enzyme activity. Therefore, it is recommended to use the complete larvae when data is just expressed in total activity (U/larva) in order to avoid the above-mentioned issues, whereas dissected larvae may be used when enzyme activity is expressed as in specific activity units (U/mg protein). However, it should be considered that when dissection is not possible due to the small size of larvae or due to other reasons, enzymes activities expressed in specific activity units will be underestimated or may lead to potential interpretation errors. This is generally found in ontogenic studies describing the activity of digestive enzymes, when at larger larval sizes or older ages, enzyme activity decreases even though this does not indicate that there is a reduction in the digestive performance of specimens rather than a higher content of protein in crude homogenates. Thus, authors recommend always using both types of quantification of enzymatic activity, as a specific activity (U / mg protein) and as a total activity (U / tissue or $\mathrm{U} /$ larva, $\mathrm{U} / \mathrm{g}$ of tissue), for a better understanding of the physiological response in fish to experimental treatments or sample origin (Gisbert et al., 2018).

In addition, the time of the day for sampling must be considered in order to avoid the potential effect of the circadian rhythm on digestive enzyme activities (Montoya et al., 2010). Although some studies have shown an almost stable amount of pepsin measured during a 24-h cycle, Yúfera et al. (2012) showed that daily changes in mRNA expression of pepsinogen (precursor of pepsin) were not particularly related to the moment of food supply, but modulated by the circadian cycle. The results clearly evidenced how the mRNA transcripts, which showed low levels during the diurnal and feeding period, were 
overexpressed during the night-time, this meaning that the transcriptional effort was done during the resting hours. This suggested that the translation of pepsinogen mRNA to protein might be constant in order to maintain a stable amount of this zymogene. Thus, special attention should be taken when combining biochemical and molecular tools for assessing the activity of digestive enzymes, since just using gene expression assays can drive to inconclusive or biased results. In the case of fish larvae, additionally, other authors recommended to scale fish larval development using thermal units (temperature degree days), and complement this information with data on larval size (standard or total length) for each age considered and/or the stage of development by using externally visible anatomical features of the specimen (Gisbert et al. 2018).

Summarizing, if we consider that acid pepsin-like proteases are soluble and stable at acid $\mathrm{pH}$, the recommendation is to perform the extraction in distilled water and once the extract is clarified by centrifugation, adjust the $\mathrm{pH}$ to 2 with $1 \mathrm{M} \mathrm{HCl}$, allow to stand $1 \mathrm{~h}$ in an ice water bath (experimental data is described below), centrifuge the extract again and keep it in small aliquots $(200 \mu \mathrm{L})$ at $-80{ }^{\circ} \mathrm{C}$. The use of alkaline buffer is not recommended, since the use of these buffers will difficult $\mathrm{pH}$ adjustment to 2 when dealing with measurements of acid pepsin-like acid protease activity. Although the measurement of acid protease has a TCA clarification step of the reaction mixture (RM), before the spectrophotometric measurement, it is recommended to clarify the enzymatic extract, at least at $15,000 \times \mathrm{g}, 15 \mathrm{~min}$ at $4{ }^{\circ} \mathrm{C}$ in order to reduce the suspended particle effect (increasing turbidity) in other spectrophotometric measurements, such as the quantification of soluble proteins (Bradford 1976).

\subsubsection{Determination of acid protease activity: the use of standard protocols}

Authors have also revised the methodology for pepsin-like acid protease quantification reported in the literature. In particular, the methods applied to quantify fish 
stomach acid protease activity were revised in the 31 studies retrieved from the bibliography (Table 2). The most common protocol for assessing the activity of stomach acid pepsin-like protease in fish (51.6\% of the studies) is the one proposed by Anson (1938), whereas $16.1 \%$ of authors used method of Hidalgo et al. (1999). However, these authors cited the work of Kunitz (1947), which was later modified by Walter (1984). Similarly, $6.5 \%$ of the revised studies cited the work of Lazzari et al. (2010), but Lazzari cited the study of Kunitz (1947) that was also modified by Hidalgo et al. (1999). The above-described concatenation of citations makes difficult the traceability of the methodology used and the proper interpretation of the results derived from those studies, which also suggests the little care of authors when reporting the literature cited. Other methodologies have been also utilized, but less frequently $(\leq 5 \%)$ as shown in Table 2 . Regardless of the method used, authors found some relevant inaccuracies in acid pepsinlike acid protease determination that need to be addressed as follows.

Firstly, among the only four studies that explicitly report the reaction volumes, these varied from 1,000 to $7,900 \mu \mathrm{L}$. The rest of the studies $(n=29)$ did not report the volume of the reaction, so it is assumed that they used the volumes indicated by the reference cited by these authors $(22.61 \%$ used the Walter's method cited by Hidalgo et al. (1999)). The studies that used the Hidalgo's method for pepsin quantification (cited by Lazzari et al. 2010) used a volume of $7,700 \mu \mathrm{L}$. In addition, $6.5 \%$ of the studies used the Worthington's method that used a volume of $8,000 \mu \mathrm{L}$, whereas the majority of them (51.6\%) used the Anson's method, which used $16,000 \mu \mathrm{L}$ of reaction volume. This is of special relevance since the assay mixture volume is fundamental for enzyme unit calculations and different enzyme activity values might be obtained if proper reaction volumes are not correctly considered. 
In addition, to the reaction mixture, the substrate used for enzyme quantification is also of importance. Thus, regarding acid protease substrate, $74.2 \%$ of the revised studies used hemoglobin, whereas $25.8 \%$ of them used casein. Not only the substrate changed among studies, its concentration in the reaction mixture also varied, as well as the substrate concentration that ranged from $0.96 \%$ to $2.38 \%$. Substrate concentration is an important factor for proper standardization of the enzyme reaction, since according to the MichaelisMenten's law substrate concentration in the reaction mixture directly affects enzyme activity. In addition, substrate quantity must be enough to be always working with the substrate in excess. Regarding the reaction buffer, different solutions are reported in the literature. In particular, some authors $(3.2 \%)$ used $\mathrm{KCl}(200 \mathrm{mM})$ at $\mathrm{pH} 2$; others $(3.2 \%)$ used sodium acetate- $\mathrm{HCl}(250 \mathrm{mM})$ at $\mathrm{pH} 3$; and the same proportion of authors used phosphate buffer at pH 2 (Table 3). The rest of studies (91.4\%) did not report specifically the buffer employed, so it is assumed that they used the buffer indicated by the reference cited by these authors $(45.2 \%$ of them used distilled water- $\mathrm{HCl}$; and $19.4 \%$ used $\mathrm{KCl}-\mathrm{HCl}$ at $\mathrm{pH} 3$, whereas only $3.2 \%$ of them did not mention it). The above-mentioned buffers and solutions may be considered correct according to the buffer working $\mathrm{pH}$, with the exception of phosphate and acetate buffers, because $\mathrm{pH} 3$ or below are out of the working $\mathrm{pH}$ interval, for both cited buffers. If possible, authors recommend measuring the real $\mathrm{pH}$ of the empty fish stomach (Lückstädt 2012). Thus, it is advisable to measure pepsin-like acid protease at $\mathrm{pH}$ values of 2.0 ; i.e., using just $\mathrm{HCl}$ to adjust the substrate $\mathrm{pH}$ (Anson 1938). Regardless of the use of ions as $\mathrm{K}^{+}(\mathrm{KCl}$ of $\mathrm{KCl}-\mathrm{HCl})$ as previously indicated by some authors, it is recommended to firstly evaluate if there actually exists this dependence and in case of an affirmative answer, then test at which concentration of ions is required.

There also existed a remarkable variability in the temperature at which acid pepsin-like protease was determined among the consulted studies. In particular, from the 
twelve studies that explicitly reported the reaction temperature, this parameter largely varied. Reaction temperature and their relevance in terms of consulted studies is as follows: $20{ }^{\circ} \mathrm{C}(3.2 \%), 30{ }^{\circ} \mathrm{C}(6.5 \%), 37^{\circ} \mathrm{C}(22.6 \%), 40{ }^{\circ} \mathrm{C}(3.2 \%)$ and $50{ }^{\circ} \mathrm{C}(3.2 \%)$. The rest of studies did not provide specific information on the reaction temperature, so it is assumed that they used the temperature indicated by the reference cited by these authors $\left(22.6 \%\right.$ used $37^{\circ} \mathrm{C}$, and $38.7 \%$ used $\left.25^{\circ} \mathrm{C}\right)$. Considering that fish are poikilothermic animals, the reaction temperature will have a deep impact on the enzyme activity, the higher reaction condition the higher pepsin activity when enzyme activity is measured within the biological thermal limits of the species. The incubation time varied from 10 to 60 min, a time span that may vary depending on the species and developmental stage evaluated. Generally, the longer the incubation time used by researchers, the detection of lower pepsin activities in tissue or whole larval homogenates. Thus, it is recommended that the incubation time should be between 15 to $60 \mathrm{~min}$, according to enzyme acid protease activity of samples, in order to work always with substrate excess during hydrolysis.

The above-mentioned analysis indicates that most of the assays for measuring acid pepsin-like protease activity were conducted following protocols developed for homoeothermic organisms with body temperatures ranging from 37 to $38^{\circ} \mathrm{C}$, a range of temperatures really unusual for fish. Therefore, it is strongly recommended that the activity of fish acid protease, and other enzymes, should be determined not even at the optimum temperature determined by in vitro studies (i.e., $40-50{ }^{\circ} \mathrm{C}$ see Nalinanon et al. 2008 ), but at the physiological temperature in which fish species develop according to their temperature preferendum. A temperature of $25^{\circ} \mathrm{C}$ in the $\mathrm{RM}$ ( $\mathrm{RM}$ is considered when protease is acting on substrate) may be the most appropriate for most fish species inhabiting temperate waters according to Gisbert et al. (2018). 
Regarding the method for stopping protease reaction, only six studies that explicitly reported the final TCA concentration in the assay mixture; while TCA levels ranged from 4 to $10 \%(\mathrm{w} / \mathrm{v})$. The rest of studies did not provide details on the final TCA in the assay mixture, so it is assumed that they used the concentration indicated by the reference cited by these authors (58.1\% adjusted the TCA final concentration to $3 \%$, and $19.4 \%$ of authors adjusted it to $4 \%$ the TCA final concentration, whereas $3.2 \%$ of authors did not indicate it). Only one study explicitly reported the use of filtration to separate TCA soluble digestion products from the assay mixture. The rest of studies did not report specifically the step used to separate TCA non-precipitable digestion products from the assay mixture, so it is assumed that they followed the method indicated by the reference cited $(61.3 \%$ of authors used filtration on Whatman filter paper, $22.6 \%$ of them centrifuged the reaction mixture at $1,800 \times \mathrm{g}$ for $10 \mathrm{~min}$, whereas $3.2 \%$ did not provide any information on this issue). Another issue to be considered when revising different protocols, it is the assay mixtures may rest before centrifugation or filtration, which varied according to the analytical considered. In particular, Anson (1938) recommended that samples did not need to rest before filtration, whereas Worthington (1993) indicated to the reaction mixture should rest for $5 \mathrm{~min}$, and Hidalgo et al. (1999) for $60 \mathrm{~min}$. The reasons for such variations are not really known and the impact of this resting time on final enzyme quantification is neither known.

The last step in enzyme quantification is the measurement of the absorbance of the reaction mixture. All direct measurements of absorbance of the hydrolyzed products were done at $\lambda=280 \mathrm{~nm}$; in contrast, the colour developed by the Folin-Ciocalteau reagent on hydrolyzed products was measured at $\lambda=650$ or $\lambda=700 \mathrm{~nm}$ (Table 3 ). Many studies (61.2\%) did not report specifically the wavelength used to measured digestion products from assay mixture after TCA addition, so it is assumed that they followed the method 
indicated by the reference cited by these authors. In the case of Anson method (1938) no specific wavelength is mentioned, rather than just indicating that it was measured under the blue colour wavelength, which is $\lambda=700-750 \mathrm{~nm}$. A final recommendation when measuring the absorbance at $\lambda=280 \mathrm{~nm}$ is to use quartz cuvettes or microplates in order to not affect real absorbance values.

Finally, another issue that authors detected when reviewing the literature is that different studies used different molar extinction coefficients $\left(\mathrm{MEC} ; \mathrm{M}^{-1} \mathrm{~cm}^{-1}\right.$, for tyrosine quantification, while others used a tyrosine standard curve. Among the revised studies, $6.8 \%$ of them used a MEC of 0.005 or 0.008 (according to authors), 3.2\% of them used a MEC value of 0.008 , but expressed in $\mu \mathrm{g} / \mathrm{mL}$, while $9.7 \%$ of the studies used a tyrosine standard curve, but no curve equation was provided in those works. The rest of studies $(80.6 \%)$ did not report any information on this issue, so it is assumed that they followed the method indicated by the reference cited by these authors. Thus, $64.5 \%$ of authors used just a single tyrosine standard solution $(5 \mathrm{mM})$ as reported by Anson (1938), Hidalgo et al. (1999) and/or Lazzari et al. (2010), whereas others used a full standard curve (as reported by Dabrowski \& Glogowski, 1977; Liu et al. 2008), and just $3.2 \%$ of authors used a $\mu \mathrm{g} / \mathrm{mL}$ EC of 0.005 . The rest of revised studies (12.9\%) used just the absorbance units at $\lambda=280$ nm (Table 3).

The reported variability of the previous methods for the quantification of acid protease activity have a direct effect on the results and on the comparison of data among different studies, as well as the definition of the used protease units. Regarding acid protease unit definition, a wide variety of units are used in the literature. Among the studies revised, $9.7 \%$ of the them used $1 \mu \mathrm{mol}$ or mmol of tyrosine released per min, $35.5 \%$ of them used $1 \mu \mathrm{g}$ of tyrosine released per min, and $9.7 \%$ of them used $1 \mathrm{mg}$ of tyrosine released per min. In addition, $3.2 \%$ of the studies used 1 absorbance unit at $\lambda=280$ 
$\mathrm{nm}, 3.2 \%$ of them used 1 absorbance unit at $\lambda=680 \mathrm{~nm}$, whereas $3.2 \%$ of them used BAEE units (Alarcon et al. 1998); however, because Na-Benzoyl-L-arginine ethyl ester hydrochloride (BAEE) is a substrate for trypsin, it should be considered an author typographical error). The rest of studies did not report specifically acid protease unit definition, so it is assumed that they used the unit definition indicated by the reference cited by these authors. In particular, $12.9 \%$ of the authors used $1 \mu \mathrm{g}$ of tyrosine released per min according to Hidalgo et al. (1999); 9.7\% of them used 1 milliequivalent (mmol) of tyrosine (Anson, 1938), 3.2\% of them used 0.001 absorbance units at $\lambda=280 \mathrm{~nm}$ (Worthington 1993). A 3.2\% of consulted studies did not indicate it. As an example of data variability, Table 4 resume the comparison of acid pepsin-like protease units in fish.

\section{Developing a new protocol for acid pepsin-like protease}

The first published procedure for quantifying the activity of acid-like proteases was from Anson (1938). The spectrophotometric protocol described by the former author is as follows: in a test tube, $1 \mathrm{~mL}$ of enzyme solution is added to $5 \mathrm{~mL}$ of substrate $(2 \%$ hemoglobin- $\mathrm{HCl}, \mathrm{pH}=1.6$ ) solution (at $25{ }^{\circ} \mathrm{C}$ ). After 10 minutes, $10 \mathrm{~mL}$ of $0.3 \mathrm{~N}$ trichloracetic acid (TCA) is added, the tube is shaken vigorously, and the suspension is filtered through a Whatman ${ }^{\circledR}$ filter Grade 3. The colour value of the digestion products is measured using $5 \mathrm{~mL}$ of the digestion filtrate (in a $50 \mathrm{cc}$. Erlenmeyer flask) and $10 \mathrm{~mL}$ of $0.5 \mathrm{~N}$ sodium hydroxide, and $3 \mathrm{~mL}$ of the phenol Folin-Ciocalteau reagent. After 2-10 minutes, the colour is read using a blue glass filter. A tyrosine standard $(0.0008$ milliequivalents in $5 \mathrm{~mL}$ of $0.2 \mathrm{~N} \mathrm{HCl}$ ) is used to calculate tyrosine equivalents released by protease hydrolysis. For acid pepsin-like protease quantification, the Anson's method is the 
reference most generally cited, including the Worthington's method (1993). Regarding this last one, Worthington proposed the use of the rate of hydrolysis of denatured hemoglobin, considering that 1 acid protease unit increased 0.001 absorbance units at $\lambda=280 \mathrm{~nm}$ by the presence of TCA non-precipitable hydrolysis products, per minute at $37^{\circ} \mathrm{C}$, under the specified conditions. A tyrosine molar extinction coefficient of 1,250 for protease quantification has been generally used (Faulk \& Holt 2009).

The deficiencies of using the absorbance of the blue colour generated by the reaction between the hydrolysis products with the Folin-Ciocalteau reagent is that it reacts only with tyrosine and tryptophan according to Anson (1938). Thus, considering that proteins are not only formed with these two amino acids, the level of hydrolysis in the sample is potentially underestimated. In contrast, this method does not allow determining whether these amino acids are free or associated with peptides. The above-mentioned limitations indicate that it is not possible to quantify the number of hydrolyzed peptide bonds per unit of time (i.e., min). The same methodological limitation happens when it is used a tyrosine molar extinction coefficient, or when using a known concentration of tyrosine as a reference (Anson 1938) or even a standard tyrosine curve (Walter 1984).

In addition, when only the absorbance at $\lambda=280 \mathrm{~nm}$ of the assay mixture after TCA precipitation is measured (Sarath et al. 1989; Worthington, 1993), just the presence of aromatic amino acids is being quantified, leading again to an underestimation of the protease activity. In addition, no information is available whether these aromatic amino acids are free of associated to peptides. Thus, the pepsin-like activity is underestimated by only quantifying amino acids absorbed in the ultraviolet region and, on a technical perspective; it is overestimated when quantifying non-hydrolyzed amino acids, which are potentially associated with peptides. Also, this arbitrary enzyme unit (change in 
absorbance units at $\lambda=280 \mathrm{~nm}$ ) for protease activity measurement does not allow to know how many peptide bonds were actually hydrolyzed.

Based on the above-mentioned analysis of the available literature, authors evidenced the need of developing a new standardized method for acid pepsin-like protease quantification in order to facilitate reliable comparative studies on the acid digestive capacity in fish.

\subsection{Materials and Methods}

\section{Reagents and materials}

Reagents and materials obtained from Sigma-Aldrich (St. Louis, MO) included: hemoglobin from bovine blood (H2625), L-serine (S4500), trichloroacetic acid (TCA) (T6399), phthalaldehyde (P0657), sodium tetraborate (221732), sodium dodecyl sulphate (SDS) (L6026), DL-dithiothreitol (43819) and Grainer 96 well plates (M2936).

\section{Acid pepsin-like protease method: general development}

The incubation mixture proposed for this protocol is similar to that of Anson (1938), using hemoglobin as substrate for the estimation of acid pepsin-like protease. The undigested hemoglobin is precipitated with TCA, and the unprecipitated protein digested products are measured to calculate the amount (units) of acid pepsin-like protease present. However, this is not estimated with the phenol reagent (Anson 1938), which gives a blue color with tyrosine and tryptophan. Instead, this new assay is based on the quantification of amino groups released by the hydrolysis of peptide bonds; thus, we propose to use ophthalaldehyde (OPA), as proposed by Church (1983), but replacing 2-mercaptoethanol by optimal concentration of DL-dithiothreitol (DTT) in the OPA reagent formula. In addition, instead of using a single tyrosine standard solution $(0.0008 \mathrm{mEq}$ in $5 \mathrm{~mL}, 0.16 \mathrm{mM}$ as reported by Anson 1938), a free amino acid (L-serine) standard curve (0-0.8 $\mathrm{mM})$ is 
recommended. All experimental assays were done at least by triplicate. Thus, the abovedescribed procedure has been done conducting the following steps:

\section{1.1 Preparation of the enzymatic extract: effect of the extraction solution}

In order to avoid the sample effect, a single sample was used to evaluate the effect of the extraction solution on the yield of acid protease. Two specimens of amberjack Seriola rivoliana ( 8.2 and $8.5 \mathrm{~kg}$ in body weight), captured by local fishermen on the coasts of the Baja California peninsula, were preserved on ice $(12 \mathrm{~h})$ and then frozen at $-20{ }^{\circ} \mathrm{C}$ until analysis. Once in the laboratory, digestive tracts were dissected and the stomach removed, weighted (98.8 and $102.2 \mathrm{~g}$ ) and frozen at $-20^{\circ} \mathrm{C}$. Frozen stomachs were cut in $2 \mathrm{~mm}$ thick slices and these in turn were cut into four sections with the help of a knife. The tissue was divided into 8 fractions of similar weight $(24-25 \mathrm{~g})$ and frozen at $-20{ }^{\circ} \mathrm{C}$ until its use on the same day for the preparation of the enzymatic extracts. Four different extraction solutions were evaluated in order to determine the best ones for acid protease extraction yield. These solutions were $i$ ) milli Q distilled water, ii) $0.025 \mathrm{M} \mathrm{NaCl}$, iii) $0.025 \mathrm{M}$ universal buffer $(\mathrm{pH}=8)$ and $i v) 0.025 \mathrm{M} \mathrm{HCl}$.

The extraction procedure in all cases was as follows: the tissue was placed in a beaker within an ice bath $\left(0-4{ }^{\circ} \mathrm{C}\right)$; then, 3.85 volumes (w:v) of the extraction solution $(4$ ${ }^{\circ} \mathrm{C}$ ) were added, and the mixture homogenized during $60 \mathrm{~s}$ x 3 times (the use of a blade homogenizer like ULTRA-TURRAX ${ }^{\odot}$ is recommended). The homogenates were clarified by centrifugation at $15,000 \times \mathrm{x}$ during $15 \mathrm{~min}$ at $4{ }^{\circ} \mathrm{C}$. Then, aliquots $(10 \mathrm{~mL})$ were taken and these were acidified to $\mathrm{pH} 2$ with $1 \mathrm{M} \mathrm{HCl}$. Homogenates adjusted to $\mathrm{pH} 2$ and an aliquot of the same extract but not adjusted to $\mathrm{pH} 2$ were placed in an ice bath for 60 minutes. Subsequently, they were centrifuged again at $15,000 \times g\left(15 \min\right.$ at $\left.4{ }^{\circ} \mathrm{C}\right)$ and the supernatants were stored in $2 \mathrm{~mL}$ aliquots at $-80^{\circ} \mathrm{C}$ until their further analysis for acid protease activity (Section 3). 


\subsubsection{The use of hemoglobin as substrate}

In a $15 \mathrm{~mL}$ beaker, $0.1 \mathrm{~g}$ of hemoglobin (Sigma-Aldrich) was dissolved to a final volume of $10 \mathrm{~mL}$ with $\mathrm{HCl}$ at different concentrations $(0.00625,0.0125,0.025,0.05$ and $0.1 \mathrm{M})$ and the final $\mathrm{pH}$ of the substrate solution was measured ( $\mathrm{pH}$ meter MP 220, Mettler Toledo, precision of $0.01 \mathrm{U}$ ). The $\mathrm{HCl}$ concentration that gave a final hemoglobin substrate solution with a pH close to 2 was selected for further analyses.

The purity of the hemoglobin was evaluated as follows: one $\mathrm{g}$ of hemoglobin was dissolved in $0.025 \mathrm{M} \mathrm{HCl}$ to final volume of $100 \mathrm{~mL}$. The hemoglobin solution was filtered through a Whatman filter paper Grade 3. Subsequently, the filtrate was centrifuged $\left(13,000 \times g\right.$ at $4{ }^{\circ} \mathrm{C}$ for 5 minutes) and the supernatant was removed and the substrate sediment was left to dry at $60{ }^{\circ} \mathrm{C}$ for $24 \mathrm{~h}$. The weight of the filter paper with retained hemoglobin and the weight of the centrifuge tubes with substrate sediment were obtained on an analytical balance (OHAUS Corporation, USA, precision $0.0001 \mathrm{~g}$ ). This operation was conducted in order to quantify the percentage of insoluble material in the commercial hemoglobin.

\subsubsection{Effect of TCA concentration on the absorbance of the supernatant}

A volume of $400 \mu \mathrm{L}$ of fish stomach extract was added to $19.6 \mathrm{~mL}$ of $0.0125 \mathrm{M} \mathrm{HCl}$. The reaction was started by adding $20 \mathrm{~mL}$ of $1 \%$ soluble hemoglobin at $\mathrm{pH} 2$. The $\mathrm{RM}$ was incubated for 30 minutes at $25^{\circ} \mathrm{C}$. Then, the reaction was stopped by adding $500 \mu \mathrm{L}$ of TCA to $1 \mathrm{~mL}$ of the RM. Thus, in order to evaluate the optimal TCA concentrations, different TCA levels were tested: 2, 4, 6, 8, 10, 12, 14, 16, 18 and 20\% (final concentration of $1.33,2.00,2.67,3.33,4.00,4.67,5.33,6.00$, and $6.67 \%$, respectively). After TCA addition, tubes were vigorously shaken and left in rest for 10 minutes at $25^{\circ} \mathrm{C}$. Then, tubes were subsequently centrifuged at $13,000 \times \mathrm{g}$ at $25^{\circ} \mathrm{C}$ for $5 \mathrm{~min}$. The absorbance of the 
supernatant was measured at $\lambda=280 \mathrm{~nm}$ and the absorbance read at $\lambda=330 \mathrm{~nm}$ by the OPA reaction (as indicated in Section 3.1.5, using $10 \mathrm{mM}$ DTT concentration).

\subsubsection{Effect of temperature and time post-TCA addition on the absorbance of the}

\section{supernatant}

As described in the previous section, a volume of $400 \mu \mathrm{L}$ of fish stomach extract was mixed to $19.6 \mathrm{~mL}$ of $0.0125 \mathrm{M} \mathrm{HCl}$. The reaction was started by adding $20 \mathrm{~mL}$ of hemoglobin $(1 \%)$ at $\mathrm{pH} 2$. The $\mathrm{RM}$ (final volume $=40 \mathrm{~mL}$ ) was incubated 30 minutes at 25 ${ }^{\circ} \mathrm{C}$. Then, $1 \mathrm{~mL}$ of the $\mathrm{RM}$ was added to a series of centrifuge tubes containing $500 \mu \mathrm{L}$ of $20 \%$ TCA (similar as Section 3.1.3). The tubes were shaken vigorously and left in rest for $0,5,10,15,20,25$, and 30 minutes at $25^{\circ} \mathrm{C}$ and at $-10^{\circ} \mathrm{C}$. The tubes were subsequently centrifuged $\left(13,000 \times \mathrm{g}, 25^{\circ} \mathrm{C}\right.$ for $\left.5 \mathrm{~min}\right)$ and the absorbance of the supernatant read at $\lambda=$ $280 \mathrm{~nm}$., and the absorbance at $\lambda=330 \mathrm{~nm}$ following the above-mentioned procedure for the OPA reaction.

\subsubsection{Effect of DTT concentration in OPA reagent on free amino acid (L-serine)-OPA standard curve}

Preparing a standard curve of L-serine is required for proper quantification of free amine groups. For this purpose, an OPA Reagent Solution was freshly prepared at $6 \mathrm{mM}$ ophthaldialdehyde, $50 \mathrm{mM}$ sodium tetraborate, $35 \mathrm{mM}$ sodium dodecyl sulphate, and different concentration ( 0 to $20 \mathrm{mM}$ ) of DTT. In a 96 well microplate, $25 \mu \mathrm{L}$ of free amino acid (L-serine, 0 to $8 \mathrm{mM}$ ), $25 \mu \mathrm{L}$ of milli $\mathrm{Q}$ water, and $200 \mu \mathrm{L}$ of the corresponding OPA reagent were placed. After shaking of 30 seconds, the absorbance was read at $\lambda=330 \mathrm{~nm}$ (Varioskan, Thermolab Systems). The slope of the straight lines of the free amino acid (Lserine)-OPA curves (Abs at $\lambda=330 v s$. L-serine concentration) was assessed. The similar procedure was conducted using $25 \mu \mathrm{L}$ of the clarified supernatant assay mixture after 
TCA, instead of using the L-serine standard. The L-serine-OPA standard curve, for future free amino groups quantification, was selected considering the OPA reagent with DTT concentration that produce the maximum slope. A free amino acid-OPA standard curve $(0$ to $2 \mu$ moles $\mathrm{L}$-serine in $250 \mu \mathrm{L}$ assay mixture), read at $\lambda=330 \mathrm{~nm}$, was used for further pepsin quantification purposes.

\subsubsection{Determination of the optimal absorption spectrum of the amino acid-OPA-DTT complex}

In a 96 well microplate, by triplicate, $25 \mu \mathrm{L}$ of L-serine ( $4 \mathrm{mM}), 25 \mu \mathrm{L}$ of milli $\mathrm{Q}$ water and $200 \mu \mathrm{L}$ of the OPA reagent were placed. As control, L-serine was substituted by distilled water. The absorbance was read between $\lambda=300$ and $450 \mathrm{~nm}$ (Varioskan, Thermolab Systems, Waltham, Massachusetts, USA). Maximum absorbance was considered as $100 \%$ and this value was used to calculate the relative absorbance at each wavelength. In addition, the supernatant after TCA precipitation, of a real acid pepsin-like protease assay mixture, after OPA reaction was analyzed, as indicated in Section 3.1.5.

\subsubsection{Optimization of the assay volume}

Assay mixture was tested at different volumes (1000, 500 and $250 \mu \mathrm{L})$ of $0.5 \%$ hemoglobin substrate ( $\mathrm{pH} 2$ ) (final concentration of $0.49 \%$ ), the reaction was started with 5,10 , and $20 \mu \mathrm{L}$ of a stomach extract from Seriola rivoliana, adjusted to $\mathrm{pH} 2$ (final substrate:enzyme relation of 50). The RM was incubated 15 minutes at room temperature $\left(25^{\circ} \mathrm{C}\right.$ ). Reaction was stopped with 500,250 and $125 \mu \mathrm{L}$ of $20 \%$ TCA (final concentration of $6.6 \%$ ) in order to evaluate the reduction of the assay reaction volume for practical applicability purposes.

\subsubsection{Final protocol for acid pepsin-like protease}


Considering the effect of reaction volume, TCA concentration, temperature, resting time after TCA addition, and measurement of free amino groups by reaction with OPA, a new protocol to measure pepsin-like acid protease activity was designed as described below. To evaluate the performance of the new pepsin-like acid protease procedure, samples from amberjack (Section 3.1.1) were used as follows: $20 \mu \mathrm{L}$ of crude extract; $200 \mu \mathrm{L}$ of post TCA supernatant for direct absorbance reading at $\lambda=280 \mathrm{~nm}$ (Varioskan spectrophotometer, Thermolab Systems, USA) in a 96 well plate UV transparent flat bottom (Corning 6950B01, Corning Inc., Lowell, MA, USA); and using $25 \mu \mathrm{L}$ of post TCA supernatant for OPA quantification of free amino groups (reading at $\lambda=330 \mathrm{~nm}$ in a flat bottom GREINER microplate; Greiner Bio-One, Monroe, NC, USA).

Following the proposed new pepsin-like acid protease protocol, the substrates of hemoglobin $(0.5 \%)$, casein $(0.485 \%)$-hemoglobin $(0.015 \%)$, and casein $(0.5 \%)$ were evaluated in order to evaluate their performance for acid pepsin-like protease determination.

\subsubsection{Statistics}

The results were reported as means \pm standard error of the mean (SEM). Data were checked for normality and homogeneity of variances and was evaluated by means of the ANOVA test, followed by the post-hoc Tukey-Kramer multiple comparisons test. The level of significance was set at $P<0.05$.

\subsection{Results}

\subsubsection{Effect of the extraction solution}

Because when mixing the tissue extract with $0.025 \mathrm{M} \mathrm{HCl}$ sample coagulation occurred, this extraction solution was discarded for further pepsin-like acid protease quantification. The acid pepsin-like activity measured using the other extraction solutions were as follows: 
$0.752 \pm 0.026 \mathrm{U} / \mathrm{mL}$ in milli-Q distilled water, $0.734 \pm 0.028 \mathrm{U} / \mathrm{mL}$ in $0.025 \mathrm{M} \mathrm{NaCl}$, and $0.718 \pm 0.052 \mathrm{U} / \mathrm{mL}$ in $0.025 \mathrm{M}$ universal buffer $(\mathrm{pH} 8)$. When the $\mathrm{pH}$ of the tissue homogenates was adjusted to $\mathrm{pH} 2$, activity significantly changed $(P<0.05)$ as follows: $0.671 \pm 0.021 \mathrm{U} / \mathrm{mL}$ in milli-Q distilled water, $0.689 \pm 0.027 \mathrm{U} / \mathrm{mL}$ in $0.025 \mathrm{M} \mathrm{NaCl}$, and $0.636 \pm 0.027 \mathrm{U} / \mathrm{mL}$ in $0.025 \mathrm{M}$ universal buffer $(\mathrm{pH}$ 8) (the above-mentioned activity was computed using tyrosine units, using a MEC of 1,290). In general, a slight reduction in $\mathrm{U} / \mathrm{mL}$ pepsin-like acid protease activity was observed after extract acidification to $\mathrm{pH} 2(P$ $<0.05$ ). The yield of pepsin-like acid protease (U/stomach, stomach of $98.8 \mathrm{~g}$ ) was as follows: $349.2 \pm 12.2 \mathrm{U} /$ stomach in milli-Q distilled water, $340.7 \pm 13.1 \mathrm{U} / \mathrm{stomach}$ in $0.025 \mathrm{M} \mathrm{NaCl}$, and $333.4 \pm 24.1 \mathrm{U} /$ stomach in $0.025 \mathrm{M}$ universal buffer $(\mathrm{pH} 8)$. When tissue homogenates were adjusted to $\mathrm{pH}$ 2, pepsin-like activities were $311.6 \pm 9.9$ U/stomach in milli Q distilled water, $319.9 \pm 12.3 \mathrm{U} /$ stomach in $0.025 \mathrm{M} \mathrm{NaCl}$, and 295.1 $\pm 12.4 \mathrm{U} /$ stomach in $0.025 \mathrm{M}$ universal buffer $(\mathrm{pH} 8)$ (the above-mentioned activity was computed using tyrosine units, using a MEC of 1,290).

In contrast, the acid pepsin-like activity obtained by the OPA method were as follows: $2.761 \pm 0.045 \mathrm{U} / \mathrm{mL}$ in milli Q distilled water, $2.812 \pm 0.053 \mathrm{U} / \mathrm{mL}$ in $0.025 \mathrm{M}$ $\mathrm{NaCl}$, and $2.971 \pm 0.249 \mathrm{U} / \mathrm{mL}$ in $0.025 \mathrm{M}$ universal buffer $(\mathrm{pH} 8)$.

In general, a reduction in pepsin-like acid protease activity was observed after homogenate acidification to $\mathrm{pH} 2(P<0.05)$. In particular, when stomach homogenates were adjusted to $\mathrm{pH} 2$ activities changed to $2.723 \pm 0.043 \mathrm{U} / \mathrm{mL}$ in milli-Q distilled water, $2.880 \pm 0.047 \mathrm{U} / \mathrm{mL}$ in $0.025 \mathrm{M} \mathrm{NaCl}$, and $2.610 \pm 0.053 \mathrm{U} / \mathrm{mL}$ in $0.025 \mathrm{M}$ universal buffer ( $\mathrm{pH}$ 8). The yield of pepsin-like acid protease per stomach was 1,281.9 \pm 21.0 $\mathrm{U} /$ stomach in milli-Q distilled water, 1,305.5 $\pm 24.4 \mathrm{U} /$ stomach in $0.025 \mathrm{M} \mathrm{NaCl}$, and 1,379.3 \pm 115.5 U/stomach in 0.025 M universal buffer ( $\mathrm{pH}$ 8). In general, a slight reduction in yield of pepsin-like acid protease activity was observed after extract acidification to $\mathrm{pH} 2(P<0.05)$; thus, activities were $1,264.3 \pm 20.1 \mathrm{U} /$ stomach in milli-Q 
distilled water, $1,337.2 \pm 21.7 \mathrm{U} /$ stomach in $0.025 \mathrm{M} \mathrm{NaCl}$, and 1,211.6 $\pm 26.4 \mathrm{U} /$ stomach in $0.025 \mathrm{M}$ universal buffer (pH 8).

The yield (U/g of stomach) and specific (U/mg of protein) activity of pepsin-like acid protease are shown in Figure 1. The maximum specific activity $(1.74 \pm 0.06 \mathrm{U} / \mathrm{mg}$ protein, as tyrosine units; or $7.04 \pm 0.11 \mathrm{U} / \mathrm{mg}$ protein as amino-OPA units) was obtained in stomach extracts prepared with distilled water after acidification with $\mathrm{HCl}(1 \mathrm{M})$ to $\mathrm{pH} 2$, and clarification by centrifugation. The increasing in pepsin-like acid protease purity in the stomach extract was of 13.3 and 15 times higher $(P<0.05)$, after acidification to $\mathrm{pH} 2$ of distilled water extract, calculated by tyrosine and amino-OPA units, respectively.

\subsubsection{Hemoglobin substrate}

The final $\mathrm{pH}$ of the solutions of the hemoglobin substrate (1\%) dissolved in 0.0125 and $0.025 \mathrm{M} \mathrm{HCl}$ was $\mathrm{pH} 2.71$ and 2.02, respectively. Higher $\mathrm{HCl}$ concentrations $(0.05$ and 0.1 M) gave substrate final $\mathrm{pH}$ below 1.6; in contrast, the lowest $\mathrm{HCl}$ concentration resulted in $\mathrm{pH}$ values close to $\mathrm{pH}$ 3. Likewise, the experimental purity of SIGMA hemoglobin resulted in $95.62 \%$ solubility ( $4.38 \%$ of insoluble material). Results related to the effect of hemoglobin, casein-hemoglobin, and casein substrates for acid pepsin-like protease quantification is shown in Figure 2. In general, the presence of casein reduced protease activity in comparison to using hemoglobin as substrate.

\subsubsection{Effect of TCA concentration on the absorbance of the supernatant}

The effect of TCA concentration on the absorbance of the supernatant is shown in Figure

3. The supernatant absorbance at $\lambda=280 \mathrm{~nm}$ of the assay mixture decreased at final 
concentration of TCA higher than $3 \%$. The same pattern was found for free amino groups by the OPA reaction $(\lambda=330 \mathrm{~nm})$.

\subsubsection{Effect of temperature and time post TCA addition on the absorbance of the}

\section{supernatant}

The effect of temperature and rest time after stopping the hydrolysis of the substrate by the addition of TCA on absorbance values of the assay mixture is shown in Figure 4. The supernatant absorbance at $\lambda=280 \mathrm{~nm}$ of the assay mixture decreased just after $5 \mathrm{~min}$ of rest $(P<0.05)$, staying stable at higher concentrations of TCA, whereas no significant differences on temperature $\left(25^{\circ} \mathrm{C}\right.$ or $\left.-10^{\circ} \mathrm{C}\right)$ at final concentration of TCA higher than $3 \%$ were found $(P>0.05)$. In contrast, no effect was for free amino groups by the OPA reaction $(\lambda=330 \mathrm{~nm})$ in samples that rested for 0 to $30 \mathrm{~min}(P>0.05)$.

\subsubsection{Effect of DTT concentration in the OPA reagent on L-serine-OPA standard curve} and free amino groups in real acid protease assay mixture

The effect of DTT concentration in the OPA reagent on the L-serine-OPA standard curve is shown in Figure 5a. The slope [Abs $\lambda=330 \mathrm{~nm} v s$. U/micromole of free amino acid (LSerine) in the assay mixture] increased at DTT concentrations higher than $5 \mathrm{mM}$. A similar pattern was found when using a real assay mixture supernatant after TCA addition and centrifugation for pepsin-like acid protease determination using a fish stomach extract as enzyme source (Fig. 5b).

\subsubsection{Absorption spectrum of the free amino acid-OPA-DTT complex}

The absorption spectrum of the free amino acid-OPA-DTT complex is shown in Figure 6. The complex has an absorbance peak close to $\lambda=330 \mathrm{~nm}$, when comparing with the 
control absorption spectrum using distilled water replacing free amino acids in presence of the OPA reagent.

A free amino acid-OPA standard curve ( 0 to $0.2 \mu$ moles of L-serine in a $250 \mu \mathrm{L}$ assay mixture $)$ is shown in Figure 7. The equation of the curve was $y=10.777 x\left(\mathrm{R}^{2}=0.9994 ; P\right.$ $<0.05, \mathrm{n}=3)$.

\subsubsection{Reaction volume}

The effect of volume assay mixture in acid pepsin-like protease determination is shown in Figure 8. A slight difference was found in activity as tyrosine units/mL, but no difference in amino-OPA units/mL was found using 375,750 or $1,500 \mu \mathrm{L}$ assay mixture volume.

\subsubsection{Final protocol for acid pepsin-like protease determination}

The protocol has been designed and adjusted to be run in small volumes; thus, using 1.5 $\mathrm{mL}$ microcentrifuge tubes, the acid pepsin-like protease method has the following steps and reagents' order: a) tissue homogenate $(5 \mu \mathrm{L})$; b) add a volume of $250 \mu \mathrm{L}$ of $0.5 \%$ hemoglobin- $\mathrm{HCl}(\mathrm{pH} 2)$ to start the reaction; $\mathrm{c})$ incubate the mixture for 15 minutes at room temperature $\left(25^{\circ} \mathrm{C}\right.$, or the optimal temperature for the species considered); $\left.\mathrm{d}\right)$ after incubation, the reaction should be stopped with $20 \%$ TCA $(125 \mu \mathrm{L})$ and mix the volume vigorously by vortexing the microcentrifuge tube; e) after holding for 10 minutes, the assay mixture is centrifuged at $13,000 \mathrm{x} g$ for $5 \mathrm{~min}$ at room temperature to recover the supernatant containing the TCA non-precipitable products.

The quantification of the free amino groups released from hemoglobin by pepsinlike acid protease hydrolysis present in supernatant is done at microplate level as follows: add $25 \mu \mathrm{L}$ of the supernatant in a well of a flat bottom 96 well microplate (Grainer, catalog No.M2936), then, add, $25 \mu \mathrm{L}$ of milli-Q distilled water (please, not that if the volume of supernatant is modified, the volume needs to be adjusted to $50 \mu \mathrm{L}$ with milli-Q distilled 
water), and finally, add $200 \mu \mathrm{L}$ of OPA reagent. The solution should rest for 2 min at room temperature $\left(25^{\circ} \mathrm{C}\right)$, mixed for 30 seconds, and the absorbance read at $\lambda=330 \mathrm{~nm}$ in a microplate reader (Varioskan, Thermolab Systems, USA). The number of hydrolyzed peptide bonds is calculated using a L-serine standard curve, adjusting absorbance to $1 \mathrm{~cm}$ path length. One pepsin-like acid protease unit is defined as the amount of enzyme that releases a $\mu \mathrm{mol}$ of amino groups per minute, under established experimental conditions. All measurements should be done by quadruplicate.

The performance of the above-described new pepsin-like acid protease procedure, using a fish stomach extract (prepared as indicated with distilled water), amino-OPA units in comparison with the tyrosine units is shown in Figure 9.

\subsection{Discussion}

In true stomach digestion, dietary proteins when exposed to the acidic conditions found in the stomach are usually denatured; this permits them to be attacked by the gastric pepsinlike enzyme and leads to the generation of peptides of different lengths (Sarath 1989).

Regarding the preparation of the stomach's extract, we recommend to perform the extraction with 3 volumes (v:w) of milli-Q distilled water; then, homogenize the tissue for 3 times by $60 \mathrm{~s}$ in an ice water bath, and proceed with the clarification of the extract by centrifugation $\left(15,000 \times \mathrm{g}, 15 \mathrm{~min}\right.$ at $\left.4{ }^{\circ} \mathrm{C}\right)$ and $\mathrm{pH}$ adjustment to 2 with $1 \mathrm{M} \mathrm{HCl}$. Once adjusted the $\mathrm{pH}$, allow to stand the supernatant for $1 \mathrm{~h}$ in an ice water bath. After that a second clarification by centrifugation, extracts are and keep it in small aliquots $(1 \mathrm{~mL})$ at $80{ }^{\circ} \mathrm{C}$. According to the present experimental results described in Figure 1, the proposed method will provide the highest yield and specific pepsin-like acid protease activity, 
potentially increasing the purity of pepsin-like acid protease in fish stomach extracts by a single acidification-clarification step, .

Unfortunately, the above-mentioned methods (Anson 1938; Walter 1984;

Worthington, 1993) only measure, the absorbance at $\lambda=280 \mathrm{~nm}$ of the hydrolyzed products (Worthington 1993) or the absorbance generated by these products when reacting with the Folin-Ciocalteau reagent (Anson 1938). In the first case, the Worthington's method only measured the absorbance of aromatic amino acids in the ultraviolet region, whereas the Anson's protocol only measured tyrosine and tryptophan. Since proteins, including hemoglobin, are formed by 20 amino acids, these methods largely underestimate the release of total amino acids by the action of the acid protease. Therefore, the main modification of the new methodological proposal considers the quantification of the release of amino groups to calculate the number of hydrolyzed peptide bonds present in the substrate. This was achieved by using the OPA reagent that is used for alkaline protease determination (Church 1985). The OPA reagent was modified including DTT instead mercaptoethanol and adapted at the microplate level, and using a standard L-serine curve,to quantify the number of free amino groups. In addition, absorbance should be read at $\lambda=330 \mathrm{~nm}$ according to the absorption spectrum shown in Figure 6) instead of using $\lambda=$ $340 \mathrm{~nm}$.

Because only $25 \mu \mathrm{L}$ of supernatant are required to measure free amino groups, it is possible to reduce the total volume of the assay mixture of the acid protease method (see Fig. 8), which allows saving reagents and reduces the production of laboratory toxic waste. Considering the above-mentioned results, authors recommend the use of a total volume of $375 \mu \mathrm{L}$ and $5 \mu \mathrm{L}$ of enzyme extract.

Under the established experimental conditions, the use of hemoglobin as a substrate at a final concentration of $0.5 \%$ in the reaction mixture is considered sufficient, but always 
an excess of substrate must be used. Thus, the TCA precipitate in the assay indicates the presence of residual substrate in the assay mixture.

According to results shown in Figure 3, a final concentration of TCA lower than $3 \%$ in the assay mixture is not enough to full precipitation of residual products from hemoglobin digestion with high molecular weights. In addition, no effect was observed by standing the assay mixture at low temperature $\left(-10^{\circ} \mathrm{C}\right.$, Fig. 4). Considering the abovementioned results, authors recommend the use of TCA at no lower than 5\% of final concentration in the assay mixture, and stand it of 10 minutes at room temperature $\left(25^{\circ} \mathrm{C}\right)$, before centrifugation at $13000 \mathrm{x} g, 25^{\circ} \mathrm{C}, 5 \mathrm{~min}$.

The optimal DTT concentration in the OPA reagent was found at $5 \mathrm{mM}$, but in order to have an excess, authors recommend the use of DTT at final concentration of 10 $\mathrm{mM}$ (see Fig. 5b). DTT has advantages on 2-mercaptoethanol in having two thiol groups instead one, and reducing the annoying smell of OPA reagent, in comparison with original OPA reagent (Church 1983, 1985). The free amino acid-OPA standard curve (0 to 0.2 $\mu$ moles of L-serine in a $250 \mu \mathrm{L}$ assay mixture) showed a very good correlation (Figure 7). Comparing the activity of protease acid pepsin-like when using the amino-OPA units with regard to the tyrosine units, shows that quantification using the amino-OPA units has a bigger sensibility (an accuracy for measuring peptide bond hydrolysis by acid protease) than when using tyrosine units (Fig. 9). Instead of having arbitrary $\lambda=280$ absorbance units (Worthington, 1993) or blue colour developed measured at $\lambda=680-700 \mathrm{~nm}$ produced by tyrosine and tryptophan with Folin-Ciocalteau reagent (Anson 1938); this proposed method shows that it is possible to calculate the number of hydrolysed peptide bonds, using an amino-OPA standard curve, measured at equal experimental conditions than assay mixture of acid protease samples at a microplate level. According standard curve the sensitivity of the method can at least to measure $0.025 \mu$ moles of free amino groups in the 
reaction mixture. The $\mathrm{R}^{2}$ of standard curve equation indicates a very good accuracy in the quantification of the indicated concentrations of free amino groups.

Finally, considering than some authors used casein as substrate for acid protease quantification (Dabrowski \& Glogowski, 1977; Hidalgo et al. 1999; and Lazzari et al. 2010), the effect of hemoglobin, casein-hemoglobin, and casein substrates indicates that acid protease activity was increased depending on the substrate considered. The increment in activity was in this order: casein, casein-hemoglobin, haemoglobin (Fig. 2), a change that was possible due to their solubility in acidic $\mathrm{pH}$ values. Considering the abovementioned results, authors recommend the use of $0.5 \%$ hemoglobin final concentration in the assay mixture.

\section{Conclusions}

The friendly use of protocols for assessing the activity of digestive enzymes has led to its generalized use in many areas of fish biology, including aquaculture studies; however, this has resulted in some methodological and/or interpretative inconsistencies that this contribution aimed to address in order to improve the reliability of data in this field. Thus, special attention should be paid on: $i$ ) the proper preparation of stomach extract for enzymatic determinations, $i i)$ the use of the proper reaction conditions at the normal range

of $\mathrm{pH}$, temperature, and mainly on the quantification of the number of peptide hydrolyzed for acid protease unit calculation. The implementation of these recommendations, and the proposal of methodological steps, will promote the standardization of actual pepsin-like acid protease analytical procedures, as well as improve the reliability of comparative studies between different fish species or rearing procedures. 


\section{Acknowledgements}

Authors thanks to Patricia Hinojosa Baltazar, from CIBNOR for technical experimental support. This review was partially funded by the CYTED Network LARVAplus (ref. 117RT0521).

\section{References}

Alarcón FJ, Diaz M, Moyano FJ, Abellan E (1998) Characterization and functional properties of digestive proteases in two sparids: gilthead seabream (Sparus aurata) and common dentex (Dentex dentex). Fish Physiol. Biochem. 19, 257-267.

Anson ML (1938) The estimation of pepsin, trypsin, papain and cathepsin with hemoglobin. Journal of General Physiology 22: 79-89.

Bradford MM (1976) A rapid and sensitive method for the quantization of microgram quantities of protein utilizing the principle of protein dye binding. Anal. Biochem., 72: 248-254.

Church C, Swaisgood HE, Porter DH, Catignani GL (1983) Spectrophotometric assay using o-Phthaldialdehyde for determination of proteolysis in milk and isolated milk proteins. Journal of Dairy Science 66: 1219-1227.

Church FC, Porter DH, Catignani GL, Swaisgood HE (1985) An o-Phthalaldehyde spectrophotometric assay for proteinases. Annals of Biochemistry 146: 343-348.

Dabrowski K, Glogowski J (1977) Studies on the proteolytic enzymes of invertebrates constituting fish food. Hydrobiologia 52: 171-174 
Dimes LE, Haard, NF (1994) Estimation of protein digestibility I. Development of an in vitro method for estimating protein digestibility in salmonids. Comparative Biochemistry and Physiology 108A: 349-362.

Faulk CK, Holt GJ (2009) Early weaning of southern flounder, Paralichthys lethostigma, larvae and ontogeny of selected digestive enzymes. Aquaculture 296: 213-218.

German DP, Horn MH, Gawlicka A (2004) Digestive enzyme activities in herbivorous and carnivorous prickleback fishes (Teleostei: Stichaeidae): ontogenetic, dietary, and phylogenetic effects. Physiological and Biochemical Zoology 77: 789-804.

Gisbert E, Nolasco H, Solovyev M (2018) Towards the standardization of brush border purification and intestinal alkaline phosphatase quantification in fish with notes on other digestive enzymes. Aquaculture 487: 102-108.

Hidalgo MC, Urea E, Sanz A (1999) Comparative study of digestive enzyme fish with different nutritional habits: Proteolytic and amylase activities. Aquaculture, Amsterdam, v. 170, n. 3-4, p. 267-283.

Kunitz M (1947) Crystalline soybean trypsin inhibitor: II. General properties. J. Gen. Physiol. 30, 291-310.

Lazzari R, Radünz-Neto J, Pedron FA, Loro VL, Preto A, Gioda CR (2010). Protein sources and digestive enzyme activities in jundiá (Rhamdia quelen). Sci. Agric., v.67, p.259266.

Lazo JP, Darias MJ, Gisbert E (2011) Ontogeny of the digestive tract. In: Holt, G. J. (editor) Larval fish nutrition. John Wiley \& Sons, Inc, Hoboken, pp 5-46. 
Liu ZY, Wang Z, Xu SY, Xu LN (2008) Partial characterization and activity distribution of proteases along the intestine of grass carp, Ctenopharyngodon idella (Val.). Aquac Nutr $14: 31-39$.

Lückstädt C (2012) Acidification in monogastric fish: limits and potentials. AQUA Culture Asia Pacific Magazine, November/December 2012, 38-39.

Moyano FJ, Saenz de Rodrigañez MA, Díaz M, Tacon AGJ (2014) Application of in vitro digestibility methods in aquaculture: constraints and perspectives. Reviews in Aquaculture 6: 1-20.

Nalinanon S, Benjakul S, Kishimura H (2008) Tuna pepsin: characteristics and its use for collagen extraction from the skin of threadfin bream (Nemipterus spp.). Journal of Food Science 73: 413-419.

Rønnestad, I., Yúfera, M., Ueberschär, B., Ribeiro, L., Sæle, Ø., \& Boglione, C. (2013). Feeding behaviour and digestive physiology in larval fish: current knowledge, and gaps and bottlenecks in research. Reviews in Aquaculture, 5, S59-S98.

Sarath G, de la Motte R, Wagner F (1989) Protease assay methods. In: Beynon, R., Bond J. (eds), Proteolytic enzymes: a practical approach. Oxford University Press, New York, p 259.

Walter HE (1984) Proteinases: methods with hemoglobin casein and azocoll as substrates. In: Bergmeyern, H. J. (editor), Methods of enzymatic analysis. Verlag Chemie, Weinheim, Germany, pp. 270-277.

Worthington (1993) Pepsin Assay. Worthington Enzyme Manual, Worthington Biochemical Corporation. http://www.worthington-biochem.com/index/manual.html, last consulted in March 2019. 
Wu T, Sun LC, Du CH, Ca QF, Zhang QB, Su WJ, Cao MJ (2009) Identification of pepsinogens and pepsins from the stomach of European eel. Food Chemistry, 115, $137-142$.

Yúfera M, Moyano FJ, Astola A, Pousao-Ferreira P, Martínez-Rodríguez G (2012) Acidic digestion in a teleost: postprandial and circadian pattern of gastric $\mathrm{pH}$, pepsin activity, and pepsinogen and proton pump mRNA expression. PLoS One 7: e33687.

Zambonino-Infante JL, Cahu CL (2001) Ontogeny of the gastrointestinal tract of marine fish larvae. Comparative Biochemistry and Physiology 130C: 477-487.

Zambonino-Infante JL, Cahu CL (2007) Dietary modulation of some digestive enzymes and metabolic processes in developing marine fish: applications to diet formulation. Aquaculture 268: 98-105. 
Table 1

Extract preparation conditions used for acid pepsin-like protease. References are listed in the Supplementary file 1.

\begin{tabular}{|c|c|c|c|c|c|}
\hline \multirow[t]{2}{*}{ Homogenization solution } & \multicolumn{5}{|c|}{ Extract clarification RCF x $g$ (time) } \\
\hline & Reference & $\%$ & & Reference & $\%$ \\
\hline Glycine- $\mathrm{HCl}, \mathrm{pH} 2$ & 17,18 & 6.5 & 28,230 (15 min) & 28 & 3.2 \\
\hline Citrate- $\mathrm{HCl}, \mathrm{pH} 3$ & 24 & 3.2 & 23,000 (30 min) & 7 & 3.2 \\
\hline Distilled water & $2,4,11,12,15,27,28$ & 22.6 & 16,000 (15 min) & $1,10,17,25$ & 12.9 \\
\hline Tris, $\mathrm{pH} 7.5$, then adjusting to $\mathrm{pH} 2$, with $\mathrm{HCl} 1 \mathrm{M}$ & 6 & 3.2 & 15,000 (30 min) & 30 & 3.2 \\
\hline Tris, pH 8.0 & 3,8 & 6.5 & 13,500 (30 min) & $3,8,13$ & 9.7 \\
\hline Tris-CaCl2 (20 mM), pH 7.5 & 1,10 & 6.5 & 12,000 (15 min) & 11,27 & 6.5 \\
\hline Tris, $\mathrm{pH} 7.5$ & $13,16,20,25$ & 12.9 & 12,000 (12 min) & 20 & 3.2 \\
\hline Tris-Potasium phosphate (0.01M)-Glycerol (50\%), pH 7.5 & 21 & 3.2 & 11,269 (15 min) & 15 & 3.2 \\
\hline Tris-Phosphate (20 mM), pH 7.0 & 26 & 3.2 & 10,000 (30 min) & 9,12 & 6.5 \\
\hline Phosphate buffer, $\mathrm{pH} 8$ & 30 & 3.2 & 10,000 (10 min) & 24,26 & 6.5 \\
\hline \multirow[t]{2}{*}{ Nind buffer, pH 7.0} & 9 & 3.2 & 8,500 (30 min) & 18 & 3.2 \\
\hline & $5,7,14,19,22,23,29$ & & & & \\
\hline \multirow[t]{6}{*}{ Nind } & 31 & 25.8 & 5,000 (3 min) & 5 & 3.2 \\
\hline & & & 3,300 (3 min) & 4 & 3.2 \\
\hline & & & 1,700 (10 min) & 2 & 3.2 \\
\hline & & & 1,200 (10 min) & 21 & 3.2 \\
\hline & & & 1,100 (15 min) & 16 & 3.2 \\
\hline & & & Nind & $6,14,19,22,23,29,31$ & 22.6 \\
\hline
\end{tabular}

Nind: non indicated

0 
Table 2

Reference protocols and their frequency of use for assessing the activity of the larvae, digestive tract of stomach acid pepsin-like protease in fish. Values reported are based on a total of 31 retrieved articles on this topic published between 2008 and 2018 (Search chain: "acid protease AND fish"; Web of Science Core Collection $^{\mathrm{TM}}$; Thomson Reuters $\left.{ }^{\mathrm{TM}}\right)$. References are listed in the Supplementary file 1.

\begin{tabular}{|c|c|c|}
\hline Protocol & Reference & $\%$ \\
\hline Anson (1938) & $1,3,4,5,6,8,10,11,13,15,17,18,20,25,28,31$ & 51.6 \\
\hline Hidalgo et al. (1999), but Hidalgo cited to Kunitz (1947), modified by Walter (1984). & $14,19,23,26,29$ & 16.1 \\
\hline Worthington (1993) & 2,30 & 6.5 \\
\hline Sarath et al. (1989) & 7, & 3.2 \\
\hline Lazzari et al. (2010), but Lazzari cited Kunitz (1947) modified by Hidalgo et al. (1999). & 21,22 & 6.5 \\
\hline Liu et al. (2008) & 9 & 3.2 \\
\hline Dabrowski and Glogowski, 1977 & 12 & 3.2 \\
\hline Alarcon et al. (1998) & 16 & 3.2 \\
\hline Wu et al. (2009) & 24 & 3.2 \\
\hline $\begin{array}{l}\text { Kunitz (1947), modified by Walter (1984), but using hemoglobin as substrate } \\
\text { according Anson (1938) }\end{array}$ & 27 & 3.2 \\
\hline
\end{tabular}

2 
Table 3

Different experimental conditions (reaction buffer, temperature, TCA concentration, wavelength for reading, extinction coefficient, and enzyme unit definition) used for acid protease pepsin-like quantification. References are listed in the Supplementary file 1.

Temperature ${ }^{\circ} \mathrm{C}$

Reference (reported

Reference

$\%$ incubation time)

$\%$

Glycine- $\mathrm{HCl}(50 \mathrm{mM}), \mathrm{pH} 2$ Glycine- $\mathrm{HCl}(100 \mathrm{mM}), \mathrm{pH} 2$

16

3.2
16.1

20

Glycine- $\mathrm{HCl}(200 \mathrm{mM}), \mathrm{pH} 2-3$

$\mathrm{KCl}(200 \mathrm{mM}), \mathrm{pH} 2$

Sodium acetate- $\mathrm{HCl}(250 \mathrm{mM}), \mathrm{pH} 3$

$\begin{array}{ll}9 & 3.2\end{array}$

3.2

$\begin{array}{ll}23 & 3.2 \\ 24 & 3.2\end{array}$

10

Phosphate buffer, $\mathrm{pH} 2$

11

Nind

$2,3,4,5,6,8,11,12,13$,

$14,15,18,19,21,22,26$,

$27,28,29,30,31$

3.2

67.7

12

13

TCA (\%)

References

$\%$

20

30

37

40

50

Nind

7, $16(20 \mathrm{~min})$

$19(40 \mathrm{~min})$

2, 9, 10, 12 (60 min), 20,

$$
\text { 24, } 25
$$

6 (15 min)

18 (15 min)

$1,3,4,5,8,11,13,14,15$,

$17,21,22,23,26,27,28$,

29, 30, 31

$\begin{array}{crr}10 & 19 & 3.2 \\ 5.4 & 9 & 3.2 \\ 5 & 4,7,12 & 9.7\end{array}$

24

3.2

$1,2,3,5,6,8,10,11,13$,

$14,15,16,17,18,20,21$

$22,23,25,26,27,28,29$,

Nind

30,31

80.6

Extinction coefficient

$0.008\left(\right.$ ug ml $\mathrm{I}^{-1}$ )

0.005 (MEC)

Stardard curve

Nind

$19,28,31$

$1,2,3,4,5,6,7,8,9,11,1$ :

References

10

$\%$

3.2

25

3.2

3.2
9.7

80.6

$1,2,3,4,5,6,7,8,9,11,1$.

$\begin{array}{lr} & \text { Wave } \\ 3.2 & 280 \\ 3.2 & 650 \\ 9.7 & 700 \\ & \end{array}$

\begin{tabular}{rrr} 
& \multicolumn{3}{c}{} \\
280 & $2,10,16,18,19,20,23$, & \\
650 & 12 & 32.3 \\
700 & 7 & 3.2 \\
& & 3.2
\end{tabular}

$1,3,4,5,6,8,9,11,13$

$14,15,17,21,22,26,27$,

Nind

$28,29,30$

61.3

3.2 6.5

\section{2}

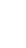


Table 4

Comparison of acid pepsin-like protease units, in stomach and larvae reported by authors, in fish

\begin{tabular}{|c|c|c|c|c|}
\hline $\begin{array}{l}\text { Specific acid protease, } \\
\text { Units/mg protein* }\end{array}$ & Unit definition used by authors & $\begin{array}{l}\text { Adjusted Units, ( } \mu \mathrm{g} \\
\text { tyrosine/min) /mg } \\
\text { protein }\end{array}$ & $\begin{array}{l}\text { Difference in relation } \\
\text { to the smallest } \\
\text { number by type of } \\
\text { tissue }\end{array}$ & Reference \\
\hline \multicolumn{5}{|l|}{ Stomach } \\
\hline 9.56 & $1 \mathrm{mg}$ of tyrosine/min & 9,560 & 211 & 5 \\
\hline $4,800 * *$ & $\begin{array}{r}\text { Nind ( } 1 \mathrm{mmol} \text { of tyrosine according } \\
\text { cited reference) }\end{array}$ & NC & NC & 11 \\
\hline 2,200 & $1 \mu \mathrm{g}$ of tirosine/min & 2,200 & 49 & 15 \\
\hline $58,710(\mathrm{mU})$ & $1 \mu \mathrm{g}$ of tirosine/min & 58.71 & 1 & 17 \\
\hline 0.25 & 1 umol of tyrosine/min & 45.30 & 1 & 31 \\
\hline \multicolumn{5}{|l|}{ Larvae } \\
\hline 11 & $1 \mu \mathrm{g}$ of tirosine/min & 11 & 7333 & 1 \\
\hline $8.31(\mathrm{mU})$ & $1 \mu \mathrm{g}$ of tyrosine/min. & 0.0083 & 6 & 3 \\
\hline $9.43 \times 10^{-5}$ & $1 \mathrm{mmol}$ of tyrosine $/ \mathrm{min}$ & 0.0017 & 1 & 4 \\
\hline \multirow[t]{2}{*}{$8(\mathrm{mU})$} & $1 \mu \mathrm{g}$ of tyrosine/min & 0.0080 & 5 & 8 \\
\hline & Nind (1 mmol of tyrosine according & & & \\
\hline $11.6 * *$ & cited reference) & NC & NC & 13 \\
\hline $1.5(\mathrm{mU})$ & $1 \mu \mathrm{g}$ of tyrosine/min & 0.0015 & 1 & 20 \\
\hline
\end{tabular}

Nind: non indicated, NC: non calculated,

* Standard deviation was not included

** cited reference is Anson (1938), unit definition: $1 \mathrm{mEq}$ of tyrosine/10 min. Difference between references

11 and 13 , is 433 times in protease units/mg protein. 
21 Fig, 1. Effect of extraction solution on yield (U/g stomach) and specific activity (U/mg protein) of acid pepsin-like protease (from Seriola lalandi stomach), a, and b, in tyrosine units, $\mathrm{b}$ and $\mathrm{c}$ in amino-OPA units..

Fig. 2. Acid pepsin-like protease activity, using a hemoglobin, casein-hemoglobin, and casein substrates.

Fig. 3. Effect of TCA concentration in reaction mixture on supernatant absorbance (Abs 280 $\mathrm{nm}$, and OPA Abs $330 \mathrm{~nm}$ ).

Fig. 4. Effect of temperature and time of rest, after precipitation with TCA (20\%) (Abs 280 $\mathrm{nm}$, and OPA Abs $330 \mathrm{~nm}$ ).

Fig. 5. a). Effect of DTT concentration in OPA reagent (L-Serine standard curve). b). $3 b$. Effect of DTT concentration in OPA reagent (acid pepsin-like protease supernatant).

Fig. 6. Absorption spectrum of OPA reagent and amino-OPA reagent complex.

Fig. 7. L-Serine-OPA standard curve $(330 \mathrm{~nm}), 1 \mathrm{~cm}$ lightlength.

Fig. 8. Effect of assay mixture volume. a). Abs 280, b). Amino-OPA units.

Fig. 9. Comparison of tyrosine and amino units. 

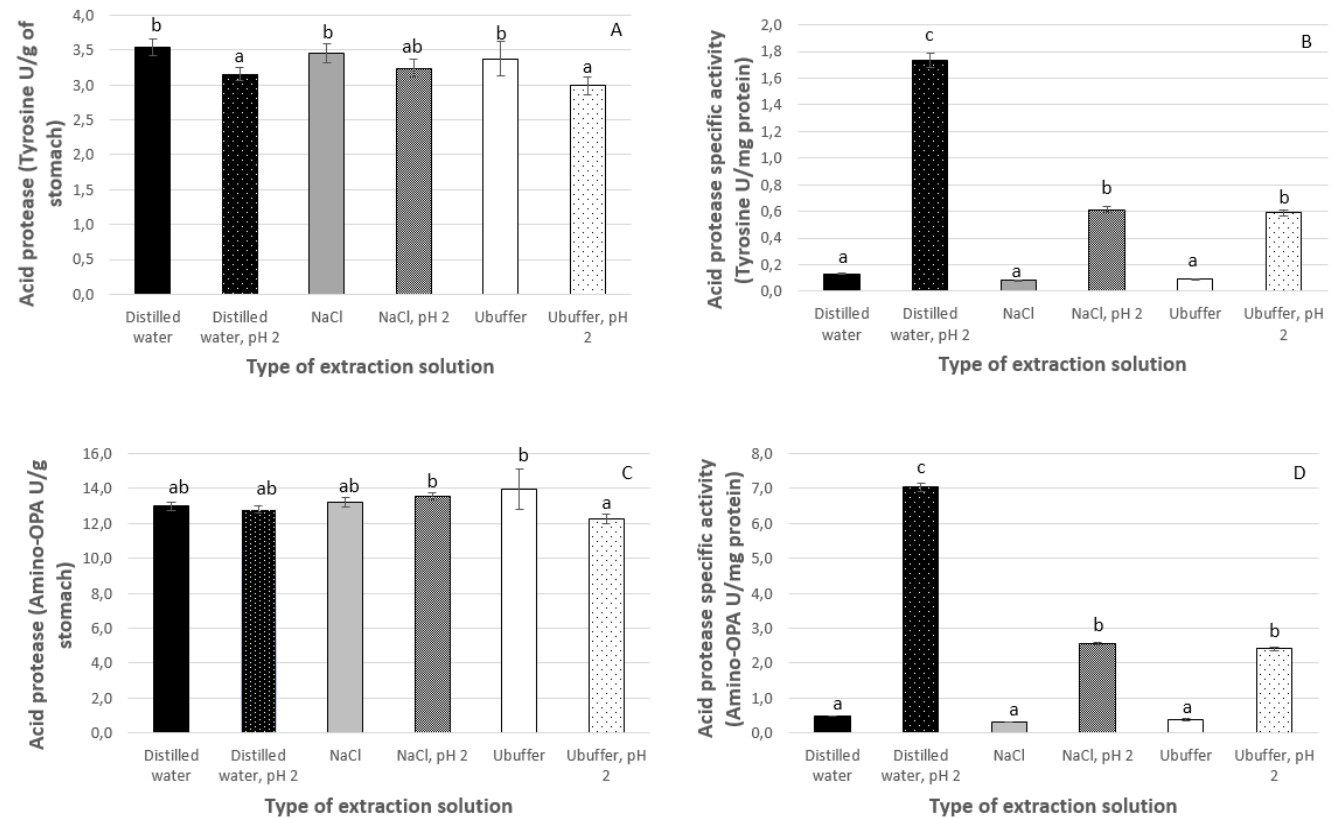

$39 \quad$ Fig. 1 


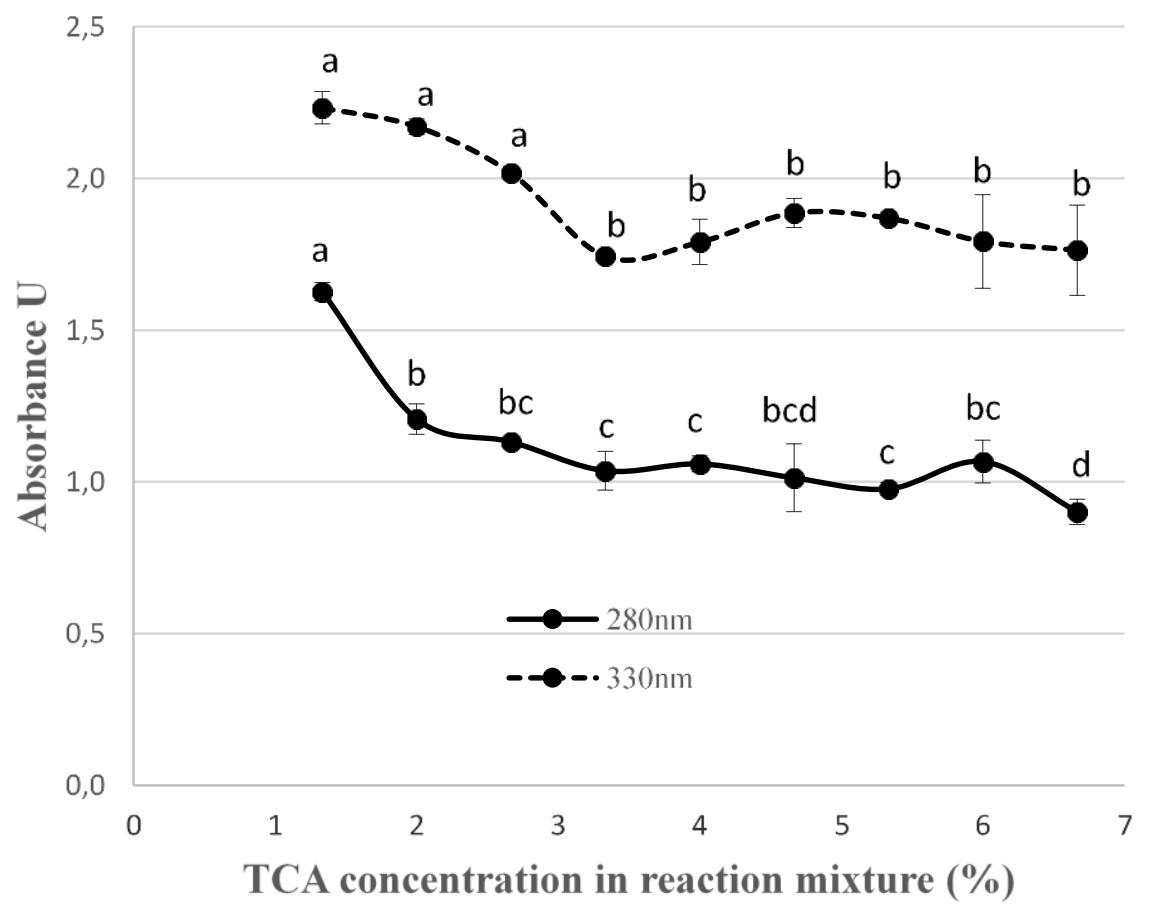

Fig. 2 


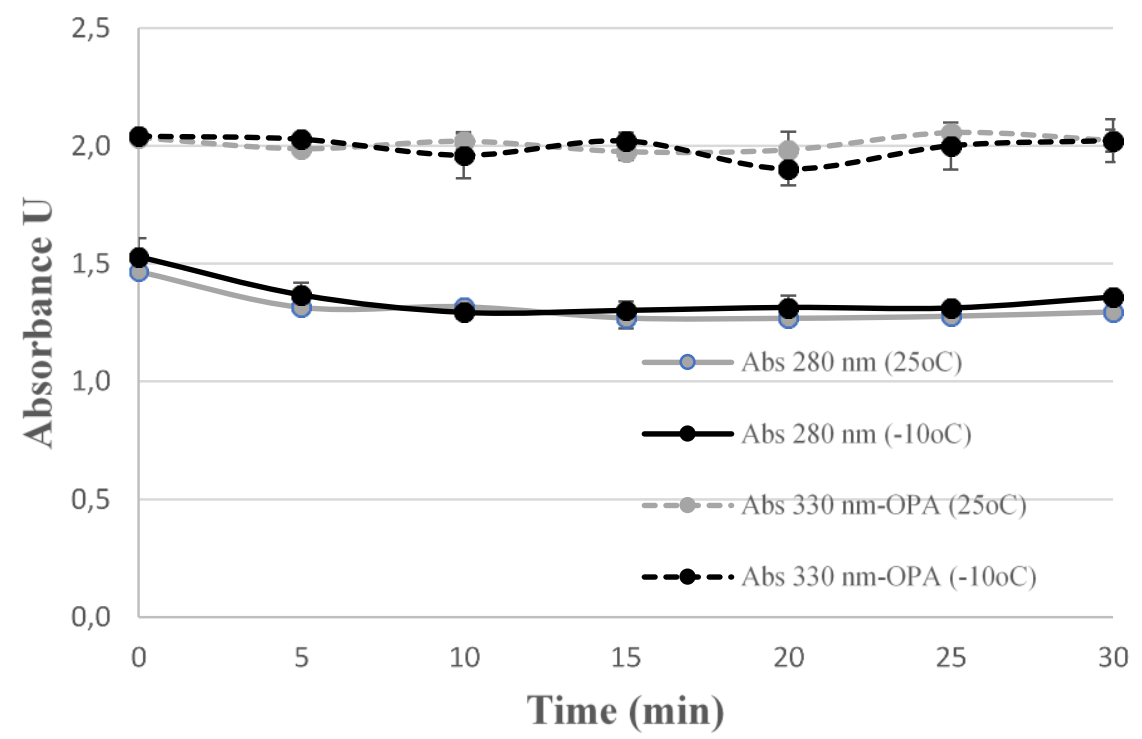

Fig. 3 

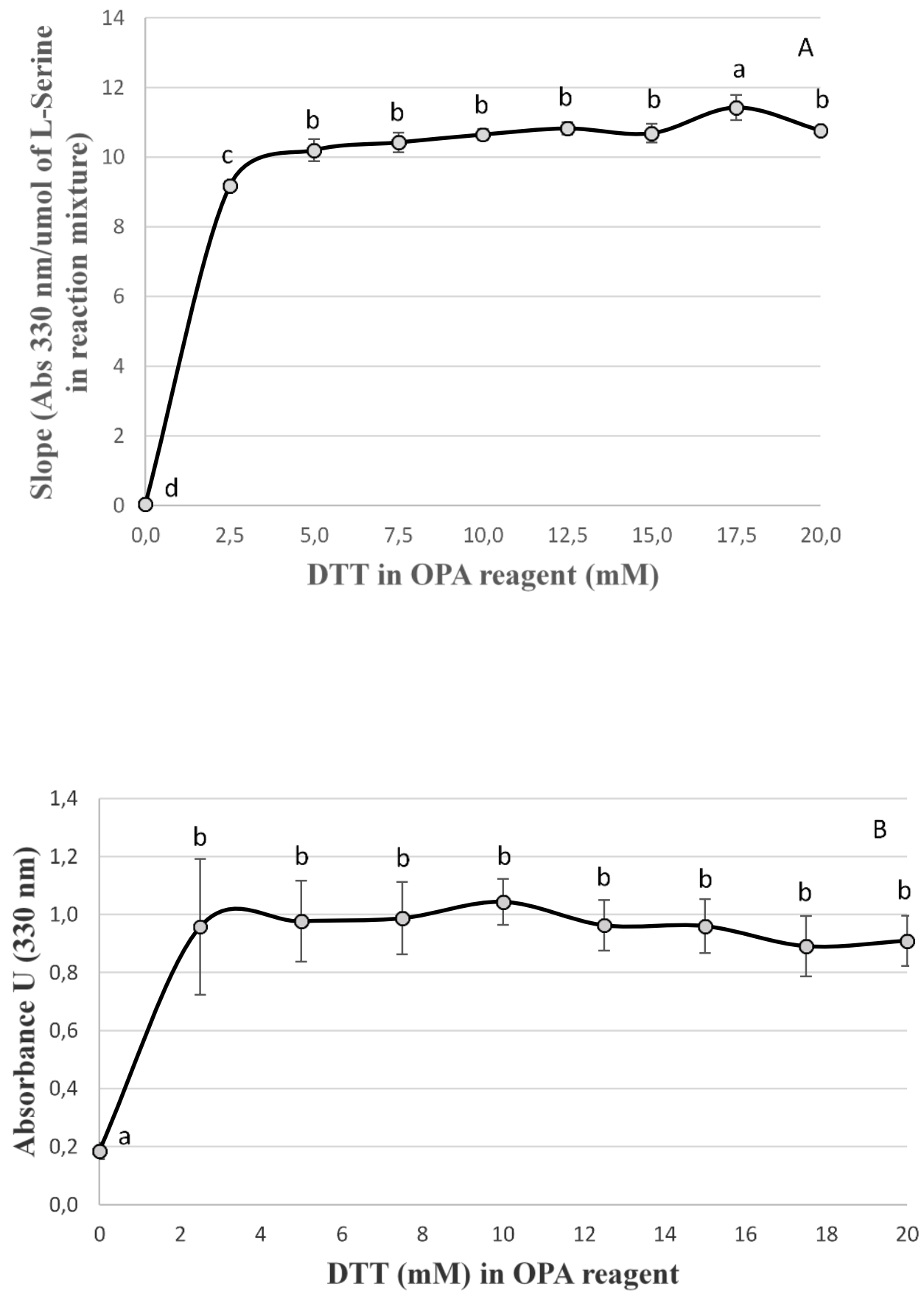

Fig. 4 


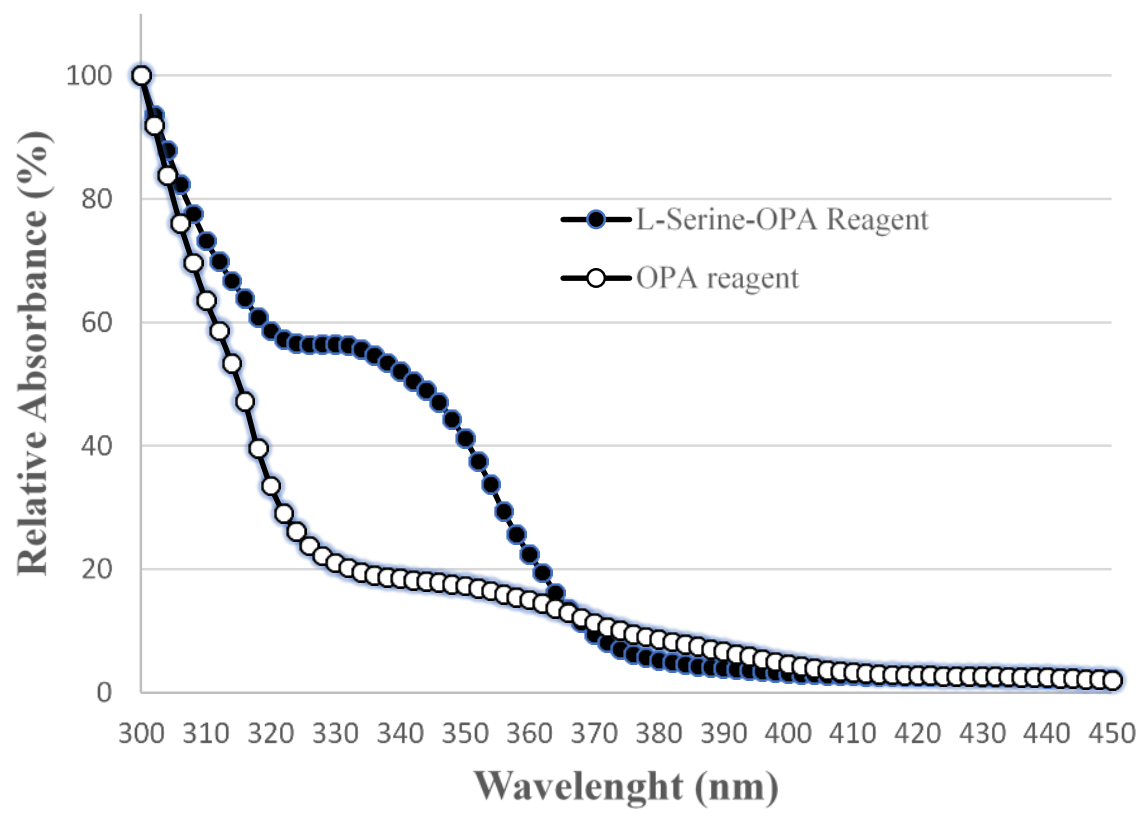

Fig. 5 

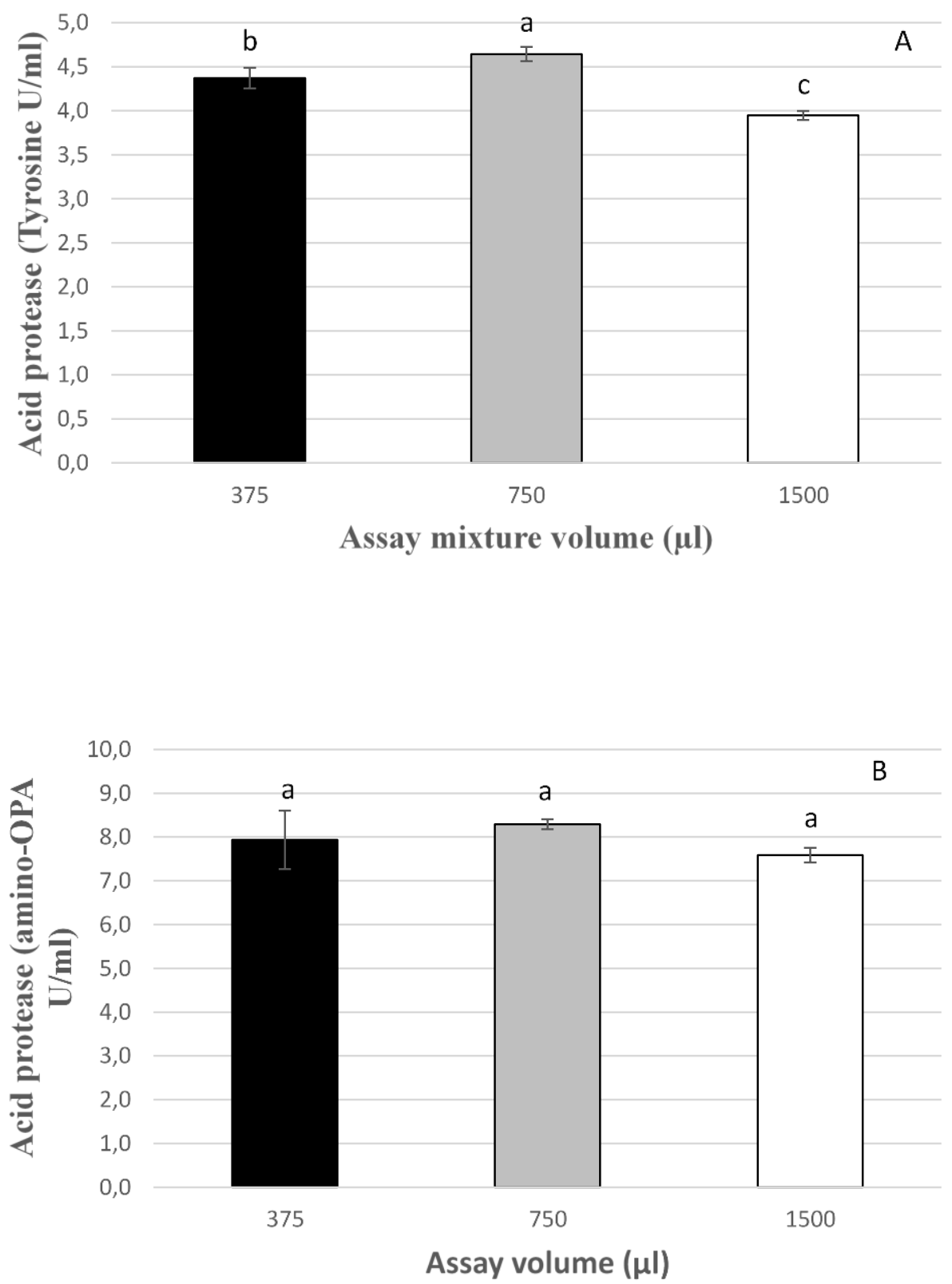

Fig. 6 


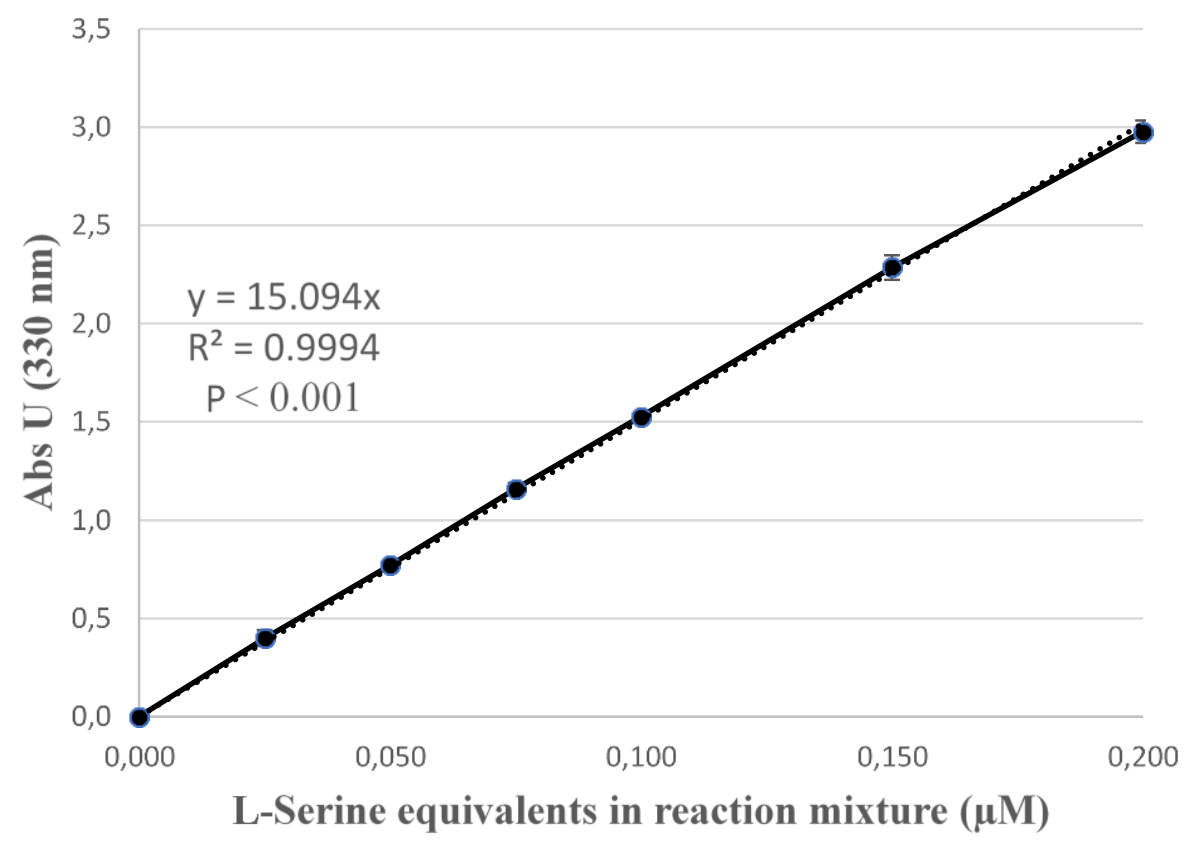

Fig. 7 


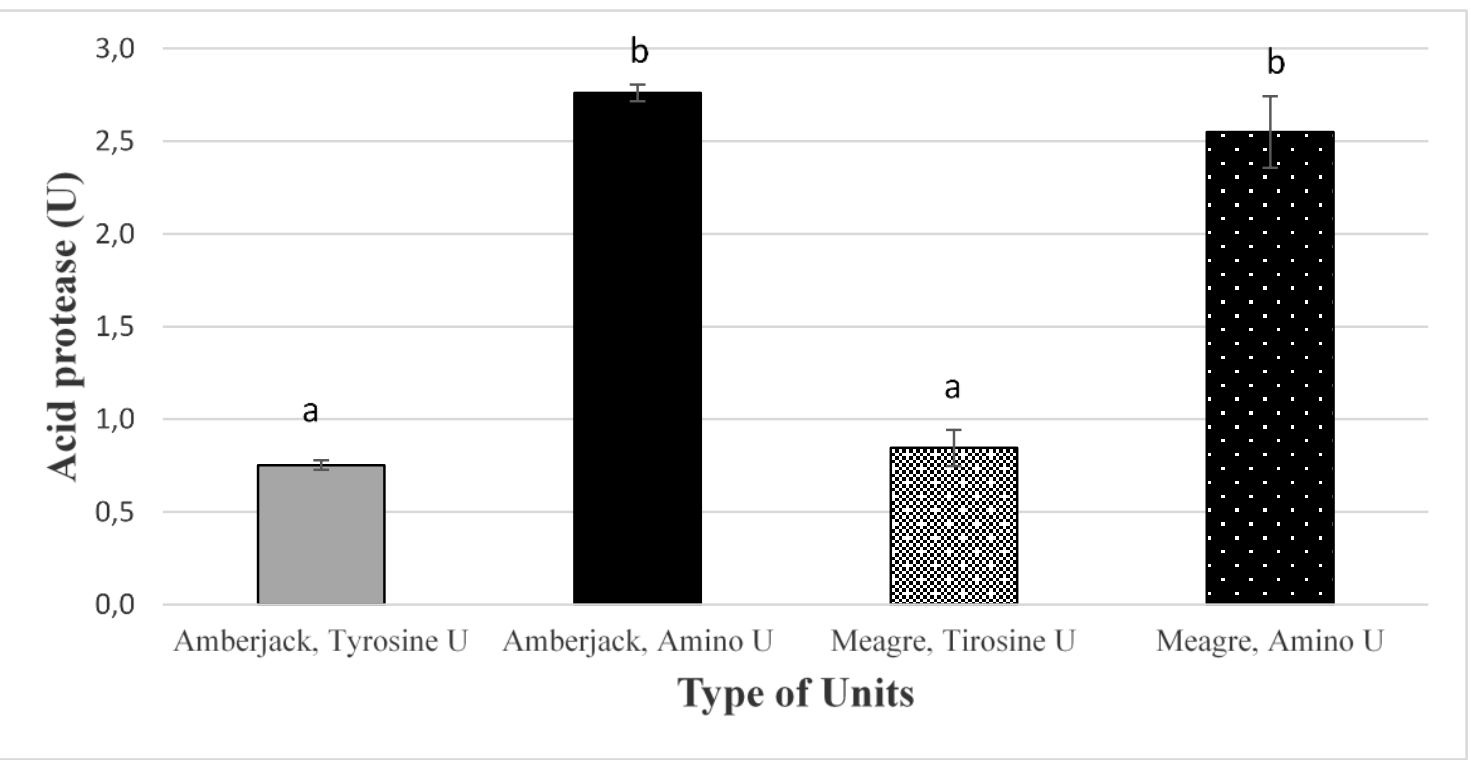

Fig. 8 


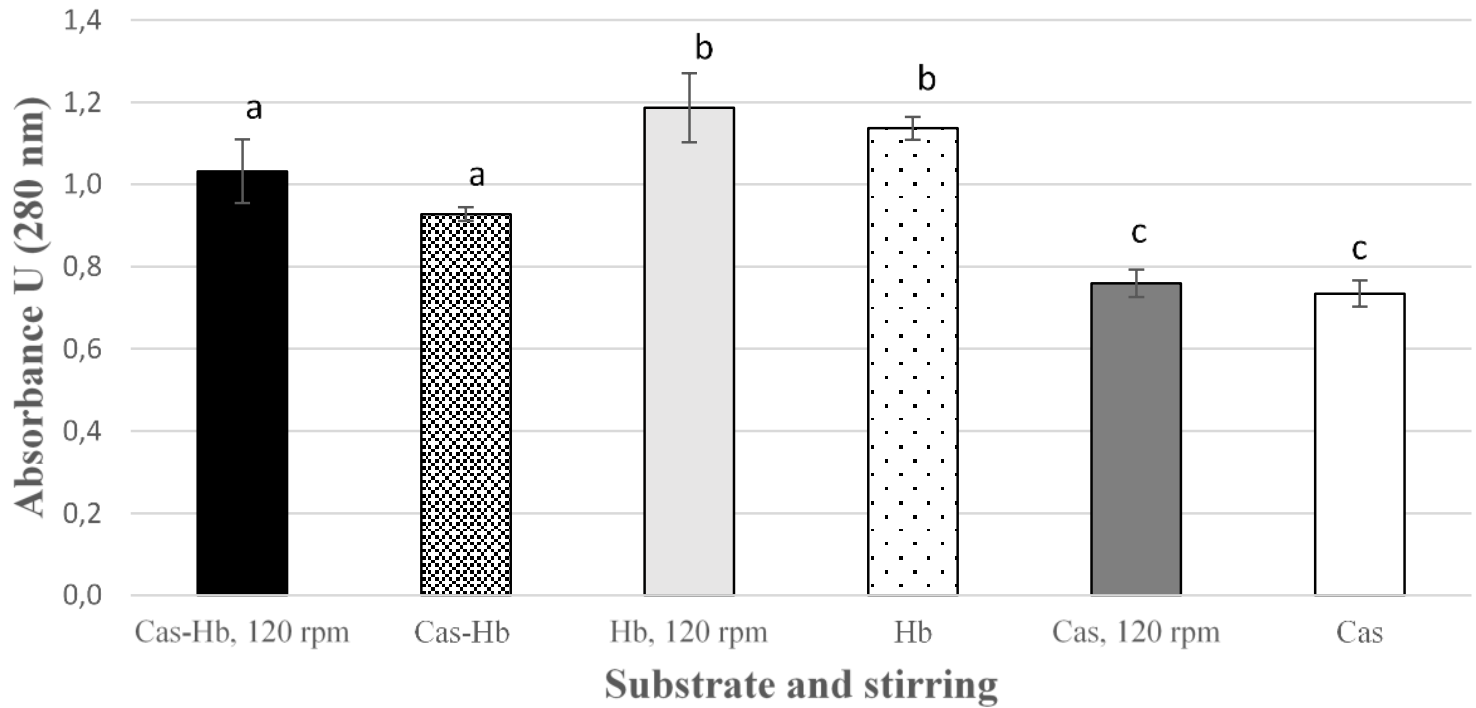

Fig. 9 


\section{Supplementary file 1}

54 List of retrieved articles from the Web of Science Core CollectionTM (www.webofknowledge.com; Thomson ReutersTM) using the following search chain "acid protease AND fish". This search chain was selected to evaluate the methodology used for acid pepsin-like protease quantification in the literature from publication years comprised between 2008 to 2018. Ontogenic development of enzymatic activity and digestive system in Jullien's golden

2. Adorian TJ, Mombach PI, Goulart FR, Pianesso D, Fagundes MB, Wagner R, Lazzari R, Neto JR, da Silva LP (2018) Effect of sex and protein level on the intermediary metabolism, growth, deposition of nutrients and profile of volatile compounds of silver catfish (Rhamdia quelen). Aquaculture Nutrition 24: 793-801.

3. Sterzelecki FC, Sugai JK, Baloi M, Passini G, de Carvalho CVA, Fracalossi DM, Cerqueira VR, (2018) Effects of increasing protein level on the performance, enzyme activity and body composition of the Brazilian sardine, Sardinella brasiliensis (Steindachner, 1879). Aquaculture Nutrition 24: 366-374.

4. Sterzeleck FC, Sugai JK, Baloi M, Passini G, de Carvalho CVA, Fracalossi DM, Cerqueira VR (2017). Effect of dietary carbohydrate to lipid ratios on growth, digestive enzyme and blood metabolites of juvenile Brazilian sardines, Sardinella brasiliensis (Steindachner, 1879). Aquaculture Research 48: 5111-5121. 
5. Guerra-Santos B, Lopez-Olmeda JF, de Mattos BO, Baiao AB, Pereira DSP, SanchezVazquez FJ, Cerqueira RB, Albinati RCB, Fortes-Silva R (2017) Synchronization to light and meal time of daily rhythms of locomotor activity, plasma glucose and digestive enzymes in the Nile tilapia (Oreochromis niloticus). Comparative Biochemistry and Physiology 204A: 40-47.

6. Gioda CR, Pretto A, Freitas CD, Leitemperger J, Loro VL, Lazzari R, Lissner LA, Baldisserotto B, Salbego J, (2017) Different feeding habits influence the activity of digestive enzymes in freshwater fish. Ciencia Rural 47: e20160113

7. Frias-Quintana CA, Dominguez-Lorenzo J, Alvarez-Gonzalez CA, Tovar-Ramirez D, Martinez-Garcia R (2016) Using cornstarch in microparticulate diets for larv icultured tropical gar (Atractosteus tropicus). Fish Physiology and Biochemistry 42: 517-528.

8. Pretto A, Silva LP, Goulart FR, Battisti EK, Loureiro BB, Eggers DP, Pianesso D (2014) In natura or detoxified tung meal in feeding Hungarian carp (Cyprinus carpio). Arquivo Brasileiro de Medicina Veterinária e Zootecnia 66: 1891-1900.

9. Garcia-Meilan I, Ordonez-Grande B, Gallardo MA (2014) Meal timing affects proteinsparing effect by carbohydrates in sea bream: Effects on digestive and absorptive processes. Aquaculture 434: 121-128.

10. Salbego J, Pretto A, Silva VMMD, Loro VL, Lazzari R, Gioda CR, Baldisserotto B (2014) Glyphosate on digestive enzymes activity in piava (Leporinus obtusidens). Ciência Rural 44: 1603-1607.

11. Guerrero-Zárate R, Alvarez-González CA, Olvera-Novoa MA, Perales-García N, FríasQuintana CA, Martínez-García R, Contreras-Sánchez WM (2014) Partial 

characterization of digestive proteases in tropical gar Atractosteus tropicus juveniles. Fish Physiology and Biochemistry 40: 1021-1029.

12. Martínez-Lagos R, Tovar-Ramírez D, Gracia-López V, Lazo JP (2014) Changes in digestive enzyme activities during larval development of leopard grouper (Mycteroperca rosacea). Fish Physiology and Biochemistry 40: 773-785.

13. Vannabun A, Ketnawa S, Phongthai S, Benjakul S, Rawdkuen S (2014) Characterization of acid and alkaline proteases from viscera of farmed giant catfish. Food Bioscience 6: 9-16.

14. Pretto A, da Silva LP, Neto JR, Nunes LMD, de Freitas IL, Loureiro, BB, dos Santos SA, (2014) In natura or reduced antinutrients forms of crambe meal in the silver catfish diet. Ciencia Rural 44: 692-698.

15. Ktari N, Bkhairia I, Jridi M, Hamza I, Riadh B, Nasri M (2014) Digestive acid protease from zebra blenny (Salaria basilisca): Characteristics and application in gelatin extraction. Food Research 57: 218-224.

16. de Menezes Lovatto N, da Silva LP, Loureiro BB, Goulart FR, Pretto A, Speroni C, S, Loro VL (2014) Effects of diets containing vegetable protein concentrates on performance and activity of digestive enzymes in silver catfish (Rhamdia quelen). Semina: Ciências Agrárias 35: 1071-1082.

17. Arı̆̆g N, Suzer C, Gökvardar A, Başaran F, Çoban D, Yıldırım Ş, Kamaci HO, Firat K, Saka, Ş (2013) Effects of probiotic (Bacillus sp.) supplementation during larval development of Gilthead sea bream (Sparus aurata, L.). Turkish Journal of Fisheries and Aquatic Sciences 13: 407-414. 
18. Rossato S, Pretto A, de Freitas IL, Battisti EK, Lazzari R, Neto JR, (2013) Addition of Jundia waste meal in diet: plasmatic biochemistry, hepatic and digestive parameters. Ciencia Rural 43: 1063-1069.

19. Sánchez-Muros MJ, Gómez-Milán E, Barroso FG, Manzano-Agugliaro F (2013) Daily and annual variation in digestive enzymes-amylase and basic and acid proteases-in gilthead sea bream, Sparus aurata. Journal of the World Aquaculture Society 44: 105-114.

20. López-Olmeda JF, López-García I, Sánchez-Muros MJ, Blanco-Vives B, Aparicio R, Sánchez-Vázquez FJ (2012) Daily rhythms of digestive physiology, metabolism and behaviour in the European eel (Anguilla anguilla). Aquaculture International 20: 10851096.

21. Ji H, Sun HT, Xiong DM (2012) Studies on activity, distribution, and zymogram of protease, alpha-amylase, and lipase in the paddlefish Polyodon spathula. Fish Physiology and Biochemistry 38: 603-613.

22. Jimenez-Martinez LD, Alvarez-González CA, Tovar-Ramírez D, Gaxiola G, SanchezZamora A, Moyano FJ, Alarcon FJ, Marquez-Couturier G, Gisbert E, ContrerasSanchez WM, Perales-Garcia N, Arias-Rodriguez L, Indy JR, Paramo-Delgadillo S, Palomino-Albarran IG (2012) Digestive enzyme activities during early ontogeny in Common snook (Centropomus undecimalis). Fish Physiology and Biochemistry 38: $441-454$.

23. Wang, XQ (Wang, Xingqiang) (2012). The effects of composite enzymes in diets on growth, carcass composition and specific enzyme activities of juvenile Paralichthys lethostigma. ADVANCES IN ENVIRONMENTAL SCIENCE AND ENGINEERING, PTS 1-6 Book Series: Advanced Materials Research Volume: 518-523 Pages: 54935499 DOI: 10.4028/www.scientific.net/AMR.518-523.5493. 
24. Suzer C, Kamaci HO, Coban D, Saka S, Firat K, Karacaoglan A (2011) Early Weaning of Sea Bass (D. labrax) Larvae: Effects on Growth Performance and Digestive Enzyme Activities. Turkish Journal of Fisheries and Aquatic Sciences 11: 491-497.

25. Balti R, Jridi M, Sila A, Souissi N, Nedjar-Arroume N, Guillochon D, Nasri M (2011) Extraction and functional properties of gelatin from the skin of cuttlefish (Sepia officinalis) using smooth hound crude acid protease-aided process. Food Hydrocolloids 25: $943-950$.

26. Nya EJ, Austin B (2011) Dietary modulation of digestive enzymes by the administration of feed additives to rainbow trout, Oncorhynchus mykiss Walbaum. Aquaculture Nutrition 17: E459-E466.

27. Montoya A, Lopez-Olmeda JF, Yufera M, Sanchez-Muros MJ, Sanchez-Vazquez FJ (2010) Feeding time synchronises daily rhythms of behaviour and digestive physiology in gilthead seabream (Sparus aurata). Aquaculture 306: 315-321.

28. Guerreiro I, de Vareilles M, Pousão-Ferreira P, Rodrigues V, Dinis MT, Ribeiro L (2010) Effect of age-at-weaning on digestive capacity of white seabream (Diplodus sargus). Aquaculture 300: 194-205.

29. Kamaci HO, Coban D, Suzer C, Saka S, Firat K (2009) Development of the gastrointestinal tract in sharpsnout sea bream (Diplodus puntazzo) larvae: histological and enzymatic ontogeny. Journal of Animal and Veterinary Advances 8: 2571-2579.

30. Faulk CK, Holt GJ (2009). Early weaning of southern flounder, Paralichthys lethostigma, larvae and ontogeny of selected digestive enzymes. Aquaculture 296: 213218. 

Ortiz-Galindo JL, Dumas S (2008) Development of digestive enzyme activity in larvae of spotted sand bass Paralabrax maculatofasciatus. 1. Biochemical analysis. Fish Physiology and Biochemistry 34: 373-384. 